\title{
Ontogenetic and seasonal trends in recent growth rates of Atlantic cod and haddock larvae on Georges Bank: effects of photoperiod and temperature
}

\author{
L. J. Buckley ${ }^{1, *}$, E. M. Caldarone ${ }^{2}$, R. G. Lough ${ }^{3}$, J. M. St. Onge-Burns ${ }^{1}$ \\ ${ }^{1}$ University of Rhode Island/NOAA Cooperative Marine Education and Research Program, Graduate School of \\ Oceanography, South Ferry Road, Narragansett, Rhode Island 02882, USA \\ ${ }^{2}$ NOAA National Marine Fisheries Service, Narragansett Laboratory, 28 Tarzwell Drive, Narragansett, \\ Rhode Island 02882, USA \\ ${ }^{3}$ NOAA National Marine Fisheries Service, Woods Hole Laboratory, 166 Water Street, Woods Hole, \\ Massachusetts 02543, USA
}

\begin{abstract}
Growth rate is a key demographic factor affecting survival and recruitment of marine fishes. Yet in the field, the patterns of change in growth rate with development and the effects of environmental variability on growth are poorly understood. We examined several factors that may contribute to the observed variability in recent (i.e. 2 to $4 \mathrm{~d}$ before sampling) growth and survival of Atlantic cod Gadus morhua and haddock Melanogrammus aeglefinus larvae on the southern flank of Georges Bank for the years 1995 through 1999. For both species, strong ontogenetic and seasonal trends in larval growth rates were apparent. A rapid initial increase in specific growth rate with larval size was observed in both species, followed by a stanza with little change in specific growth rate and finally a gradual increase with size to a maximum specific growth rate. For larva of any given size, growth rate increased as the season progressed. A variety of models were used to explore and describe the relations among growth rate, larval size, photoperiod, temperature and other variables. Generalized additive models (GAMs) with both larval size (protein content) and photoperiod terms explained $48 \%$ and $61 \%$ of the variability observed in recent growth of cod and haddock, respectively. Residuals from these models were used to examine the effects of other factors on estimated growth rates. Salinity, water density (sigma-t, $\sigma_{t}$ ), distance along the Bank, bottom depth, temperature $(\mathrm{T})$ and residual $\mathrm{T}$ (observed $\mathrm{T}$ minus the long-term mean for a given day of the year) explained small but significant portions of the residual variability in larval growth rates. These data and other considerations suggest that, while both increasing photoperiod and temperature contribute to the increase in larval growth rates observed each spring, photoperiod rather than temperature was the better proxy for the seasonal trend in larval growth rates between March and May on Georges Bank. Feeding conditions and growth of larval Atlantic cod and haddock were poor during the late winter and spring of 1995 compared with those from 1997 to 1999.
\end{abstract}

KEY WORDS: Atlantic cod $\cdot$ Haddock $\cdot$ Larvae $\cdot$ Growth $\cdot$ Photoperiod $\cdot$ Temperature $\cdot$ Diel trends

\section{INTRODUCTION}

Establishing linkages in the field between environmental variability and fish production requires measurement of key characteristics of the physical environment and biota on relevant temporal and spatial scales. This has proven more difficult than expected due to a variety of problems including: (1) selection and measurement of appropriate physical or biotic variables, (2) covariance among variables, (3) severe under-sampling, and (4) mismatches of spatial and temporal scales among variables. There is general 
agreement, however, that knowledge of the factors affecting growth and survival during the first year of life is key to understanding the linkages between the physical and biotic environment and fish production (Leggett \& Deblois 1994).

Rapid growth and high mortality characterize the larval stage of most marine fishes. The rare survivor increases in mass by 1 to 2 orders of magnitude from hatching through metamorphosis to the juvenile stage. The rates of growth and mortality together determine the rate of change in the biomass of a cohort. Interannual variability in these rates coupled with fluctuations in egg production can lead to large fluctuations in recruitment and year-class size (Houde 1989). While larval mortality generally decreases with increasing size (Peterson \& Wroblewski 1984, Bailey \& Houde 1989, Houde 1997), larval growth and development follow genetically determined patterns that are modified by environmental conditions including photoperiod, water temperature and prey availability. In the field, detailed information on the pattern of change in growth rate during the larval period is scarce.

In temperate waters, the increase in growth rate of fish larvae observed in the spring and the decrease observed in the fall has most often been attributed to or correlated with water temperature (Campana \& Hurley 1989, Munk et al. 1991, Heath 1992). However, photoperiod changes dramatically at middle and high latitudes during these same periods and may be a fundamental cause of the change in growth rates. While the differences in growth rates among different stocks at very different latitudes have been attributed to the longer photoperiod at high latitudes (Suthers \& Sundby 1996), the role of photoperiod in determining growth rate within a stock over the larval period has received relatively little attention. Since most marine fish larvae are visual feeders (Blaxter 1986), photoperiod determines the time available for feeding and consequently has a considerable impact on daily ingestion rates in marine fish larvae (Laurence 1977, Suthers \& Sundby 1996). The seasonal changes in photoperiod and water temperature are part of an annual cycle that may include cyclical changes in a number of environmental variables affecting larval growth and survival. These include prey and predator abundance, stratification, circulation and position of hydrographic fronts.

Attribution of increased growth to water temperature in the field is supported by numerous laboratory experiments that demonstrate faster larval growth rates at higher temperatures both within and among species (Pepin 1991, Buckley et al. 1993, Houde \& Zastrow 1993, Otterlei et al. 1999). Most of these experiments were run at high prey levels where food was not limiting. When food is limiting, the relationship between growth and temperature can be quite different, as seen for starved fish in the laboratory where growth rate (in this case negative) is inversely related to temperature. There have been relatively few laboratory studies examining the relationship between photoperiod and growth in marine fish larvae, particularly at reduced rations (Johannessen et al. 2000, Puvanendran \& Brown 2002). Although the role of increasing photoperiod in stimulation of endocrine production and growth in fish has been recognized since the 1950s (Brett 1979), and larval culturists routinely use long photoperiods or constant light to maximize growth, the role of photoperiod in larval ecology has received relatively little attention.

As part of the US Global Ocean Ecosystems Dynamics (GLOBEC) Northwest (NW) Atlantic-Georges Bank Program we examined the factors affecting growth and mortality of larval Atlantic cod Gadus morhua and haddock Melanogrammus aeglefinus on Georges Bank (Fig. 1) from 1995 to 1999. Both species spawn in the winter and spring on Georges Bank. Eggs and larvae are transported in the residual clockwise gyre around the Bank. Larvae are most abundant between March and May along the southern flank where our effort was concentrated. During this period of peak larval abundance, water temperatures and photoperiod gradually increase and stratification of the water column develops offshore of the tidal-mixing front located in the vicinity of the $60 \mathrm{~m}$ depth contour. In this study we document the patterns of change in recent larval growth rate with size, photoperiod, water temperature, stratification and position on the bank, among other variables. Our objective was to look across cohorts, months and years to identify the dominant variables that consistently affected larval growth. In particular we examined the roles of larval size, photoperiod and temperature in determining larval growth rates, and model the relationships among these variables. One goal of this effort is to facilitate subsequent studies focused on particular larval cohorts, months, or years when one or more processes may have a predominant effect on larval growth and survival. A related study (Buckley \& Durbin 2006) examined the relationship between larval growth rates and the prey biomass concentrations for different larvalsize classes based on monthly broadscale surveys.

We estimated recent growth of individual larvae from the ratio of RNA to DNA (R:D) and water temperature (Caldarone et al. 2003, Caldarone 2005) as nucleic acid analysis is sufficiently rapid to allow processing thousands of samples over a period of several months. This approach provides an efficient method to estimate recent growth of individual larvae over 2 to 4 d before sampling (Buckley et al. 1999) and, thus, allows a reasonable match in relevant time-scales with the persistence of physical and biotic features of the environment measured at the time of collection. 


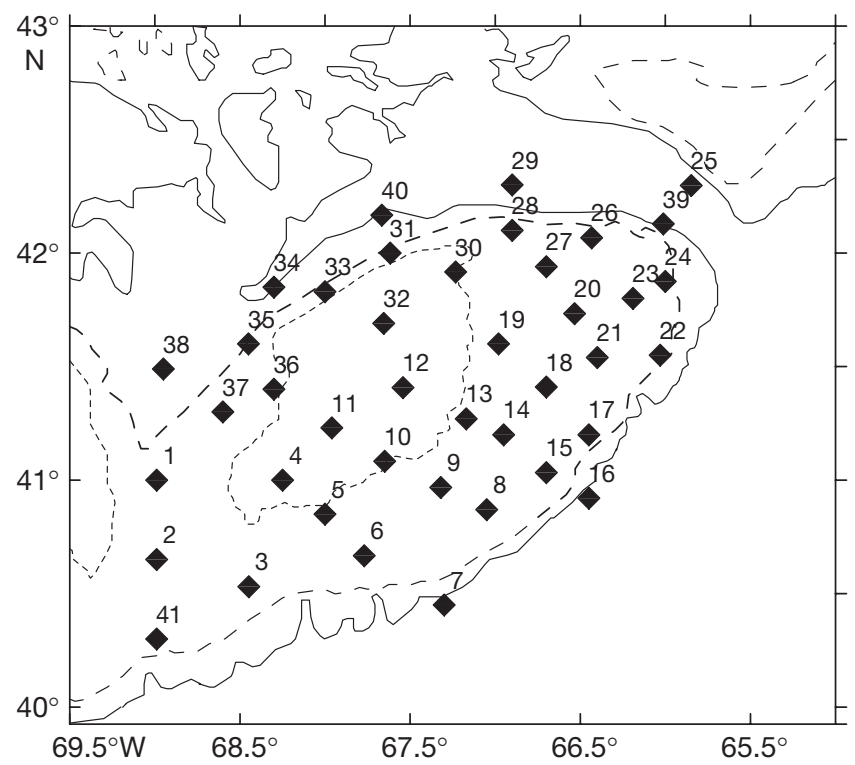

Fig. 1. Broadscale sampling locations on Georges Bank

\section{METHODS}

Field sampling and processing. Between 1995 and 1999 Atlantic cod and haddock larvae and environmental data were collected on process and broadscale cruises as part of the US GLOBEC NW AtlanticGeorges Bank Program. Although broadscale cruises were completed monthly each year between January and June, we participated only in those in April 1995 and April and May 1996, and only sampled larvae from the bongo nets used in the Program. Sampling on broadscale cruises covered much of Georges Bank at a set of standard stations (Fig. 1). Process cruises were completed monthly between March and May of 1995, 1997, and 1999. No process cruise was conducted in March of 1997 and an abbreviated cruise was completed in May 1998. Sampling on our process cruises was concentrated along the southern flank of Georges Bank in waters between 40 and $80 \mathrm{~m}$ bottom depth (Fig. 2). Each process cruise followed a similar plan that consisted of 3 to $4 \mathrm{~d}$ of depth-integrated sampling with a bongo net on a grid of stations covering much of the southern flank of Georges Bank. This was followed by a week or more of intensive, depth-discrete sampling at selected sites using the Multiple Opening/ Closing Net and Environmental Sensing System (MOCNESS, Wiebe et al. 1985) to identify associations between environmental conditions and larval production. Each year 2 or 3 sites were selected for time-series sampling based on estimated larval densities from the bongo net survey, location with respect to the tidalmixing front, and the position of fixed instrumented moorings. These stations (dense clusters in Fig. 2) were
A. Haddock
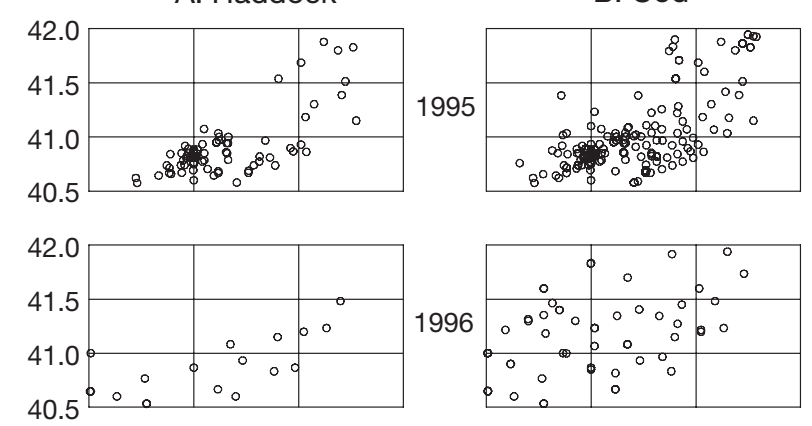

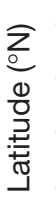
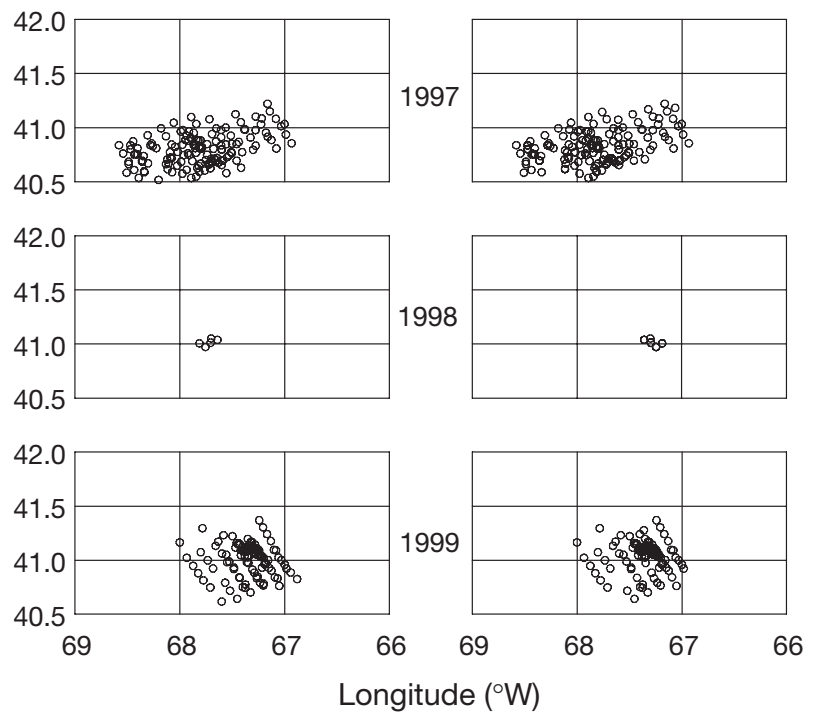

Fig. 2. Sampling sites where (A) haddock and (B) cod were collected by year. Dense clusters represent repeated sampling with MOCNESS on process cruises

occupied for a number of days and repeatedly sampled with MOCNESS. Details on sampling locations in April and May 1997 are available in Campbell et al. (2001) and Lough \& Manning (2001), respectively.

The bongo sampler consisted of two $61 \mathrm{~cm}$ nets $(333$ and $505 \mu \mathrm{m}$ mesh) and a CTD profiler (Sea Bird model 19). Tow profiles were double oblique from the surface to $5 \mathrm{~m}$ above the bottom. The $1 \mathrm{~m}^{2}$ MOCNESS, equipped with nine $333 \mu \mathrm{m}$ mesh nets, a Seabird CTD profiler and other sensors, was used to sample larval fish at discrete depths between the surface and $5 \mathrm{~m}$ above the bottom. We employed the same basic sampling protocol each year.

For MOCNESS samples, reported temperatures and water density, expressed as sigma-t $(\sigma t)$, were mean values when an individual net was open. For the bongo net sampler, values for depths greater than $60 \mathrm{~m}$ were excluded from the mean, since few cod and haddock larvae were collected with MOCNESS below $60 \mathrm{~m}$. Photoperiod, defined as the number of hours between civil sunrise and civil sunset, was estimated from the 
date of capture using longitude $67.5^{\circ} \mathrm{W}$ and latitude $41^{\circ} \mathrm{N}$ (http://aa.usno.navy.mil/data/docs/RS_OneDay. html). A stratification index $(\Delta \sigma \mathrm{t})$ was estimated as the difference in density between the water at 30 to $40 \mathrm{~m}$ depth and the surface $10 \mathrm{~m}$ (i.e. $\Delta \sigma \mathrm{t}=$ mean $\sigma \mathrm{t} 30-40 \mathrm{~m}$ - mean ot 0-10 m). An index of along-bank drift from a reference line passing through the northeast peak of Georges Bank was derived by rotating the axes by $20.2^{\circ}$ around $41^{\circ} \mathrm{N} 68^{\circ} \mathrm{W}$ so that the new longitudinal axis was approximately normal to the isobaths on the southern flank using the equation:

$$
\begin{aligned}
& \text { Along-bank distance }= \\
& \begin{array}{r}
{[(\text { Long. }+68) \times-60 \times 0.75 \times \cos (5.93)]} \\
-[(\text { Lat. }-41) \times-60 \times \sin (5.93)]+90
\end{array}
\end{aligned}
$$

On each cruise, Atlantic cod and haddock larvae from one net of the bongo sampler and from selected MOCNESS nets were sorted immediately from the catch and frozen individually in $1.5 \mathrm{ml}$ cryovials placed in the vapor phase of liquid nitrogen for later analysis of protein, RNA and DNA content (Buckley et al. 2004). To minimize the time between capture in the net and freezing, collections for biochemical analysis were made with the last nets tripped in a MOCNESS haul. The time between a net coming on deck and freezing of larvae in liquid nitrogen was minimized as much as possible and, during this interval, plankton samples and larvae were kept cold using frozen gel packs. Just before freezing, a video image of each larva was taken for determination of length. Shipboard standard length (SSL) was defined as the distance in mm between the tip of the jaw and the end of the notochord recorded on these images.

Biochemical analysis and estimation of growth rate. The RNA and DNA contents of individual larvae were estimated using one of 2 fluorometric methods that were intercalibrated extensively to insure the integrity of the time series. Samples from March and April of 1995 were run using a flow-injection analyzer and 2 fluorochrome dyes, one specific for DNA (Hoechst) and the other reactive with both nucleic acids (ethidium bromide, EB) (Caldarone \& Buckley 1991). For samples collected in May 1995 and later, we used a fluorescence microplate reader and a one-dye (EB) procedure employing RNase to digest RNA after an initial reading (Caldarone et al. 2001, 2003). The average DNA/RNA slope ratio was 2.43 for this study. Protein content of individual larvae was estimated using a colorimetric assay (bicinchoninic acid, Sigma) modified from Smith et al. (1985).

Recent growth $\left(\mathrm{G}_{\mathrm{i}}\right)$ expressed as the instantaneous protein-specific growth rate $\left(\mathrm{d}^{-1}\right)$ was estimated for each larva from water temperature $\left(\mathrm{T}_{i}{ }^{\circ} \mathrm{C}\right)$ and RNA: DNA ratio (R:D; dimensionless) using the equation:

$$
\mathrm{G}_{\mathrm{i}}=-0.147+0.009(T)+0.045(\mathrm{R}: \mathrm{D})
$$

where R:D was estimated using the microplate technique. For 1995, nucleic acid values, determined using the flow-injection technique, were first converted to comparable microplate values using an equation derived from an intercalibration study of the 2 methods (Caldarone et al. 2003). Eq. (2) was derived from laboratory experiments with larval Atlantic cod (Caldarone et al. 2003) and haddock (Caldarone 2005) reared at 3 temperatures and 3 feeding levels plus a starvation treatment. For the calibration experiments, $\mathrm{G}_{\mathrm{i}}\left(\mathrm{d}^{-1}\right)$ was calculated from samples taken at 4 to $7 \mathrm{~d}$ intervals using the equation:

$$
\mathrm{G}_{\mathrm{i}}=\left(\ln \mathrm{W}_{\mathrm{t} 2}-\ln \mathrm{W}_{\mathrm{t} 1}\right) \times\left(\mathrm{t}_{2}-\mathrm{t}_{1}\right)^{-1}
$$

where $W_{t 1}$ and $W_{t 2}$ were the individual protein content ( $\mu \mathrm{g}$ per larva) for larvae sampled on Days $t_{1}$ and $t_{2}$, respectively, assuming exponential growth. Since protein makes up the bulk of larval dry weight (Buckley \& Lough 1987), $G_{i}$ closely tracks growth in dry weight through the larval period. For both cod and haddock, larval dry weight is approximately double the protein content.

Examination of the residuals from models relating larval growth rate to R:D and temperature has suggested that growth of yolk-sac and first feeding larvae (YSFF) is somewhat overestimated (negative residuals) by the models; thus, the data on the youngest larvae had been excluded from the models (Folkvord et al. 1996, Caldarone et al. 2003, Caldarone 2005). The negative residuals could imply that either the RNA was not as active or that net retention of protein was reduced in YSFF larvae compared with older larvae. Another more likely explanation for the negative residuals is that growth of the embryo shortly after hatching was underestimated in the laboratory calibration studies, since no distinction was made between larval tissue and yolk. At hatching, yolk accounts for about $30 \%$ of the dry weight (Folkvord 2005). If the protein content or dry weight of the yolk had been excluded from values used in the growth computation, the relationship between R:D, temperature and growth rate would likely be the same for YSFF and older larvae.

Data analysis. We divided larvae into size classes based on protein content. The smallest larvae $(\leq 50 \mu \mathrm{g}$ protein) were assigned to size class 1 (lsc 1), corresponding to approximately $\leq 4.5 \mathrm{~mm}$ SSL. Larvae in lsc 1 were considered YSFF larvae. Larvae with a protein content from $>50$ to $\leq 193 \mu \mathrm{g}$ were assigned to size class 2 (lsc 2), corresponding to $\sim 4.5$ to $7 \mathrm{~mm}$ SSL. Most larvae in size class 2 would have initiated feeding and growth and are considered preflexion larvae (Lough et al. 1996). Larvae with a protein content from $>193$ to $\leq 1200 \mu \mathrm{g}$ were assigned to size class 3 (lsc 3), corresponding to $\sim 7$ to $12 \mathrm{~mm}$ SSL. Larger larvae in this size 
class would be approaching metamorphosis. Fish with a protein content $>1200 \mu \mathrm{g}$ would have completed metamorphosis into pelagic juveniles and were not included in subsequent analyses, since the relationship among R:D, water temperature and growth rate has not been calibrated for this size class.

The data were analyzed and statistics performed using SAS software (SAS Institute 2001). We used 3 data sets. The first contained a record for each individual larva $\leq 1200 \mu \mathrm{g}$ protein (IF) in size, the second consisted of net means (NM), and the third was net means by larval size class (NMLSC). The general approach was to first use all the data for individual larvae (IF) to explore the relationships among recent growth rate, larval size, photoperiod, water temperature, and day of the year (year day). Next, generalized additive models (GAMs) were used to remove the ontogenetic and seasonal trends and to generate a set of growth rate residuals $\left(\mathrm{rG}_{\mathrm{i}}\right)$ for individual larva. Averaging all variables by net gave the data set NM. Averaging by net and larval size class (lsc) yielded the data set NMLSC. In this data set an observation is the average for all larvae in a particular net in a particular size class. We then used the data sets NM and NMLSC to examine the effects of other environmental variables (including temperature) on $\mathrm{rG}_{\mathrm{i}}$. We used net means for this purpose rather than data on individual larva to avoid problems related to pseudoreplication, since all larvae collected in a given net were associated with a single set of environmental observations.

A set of temperature residuals (rT) for each species was produced by subtracting the long-term mean surface $(0$ to $30 \mathrm{~m}$ ) water temperature for a given year day from the observed water temperature when a net was open. The long-term mean surface water temperatures were obtained from the annual cycle of temperature on the southern flank of Georges Bank based on hydrographic measurements made on more than 200 cruises between 1978 and 2005 (D. Mountain pers comm).

Analysis of ontogenetic and seasonal trends. A visual examination of the data ( $x-y$ plots) revealed strong seasonal trends in larval size, growth rate and some of the environmental variables, as well as a relationship between larval size and growth rate. To explore these trends we used both linear regression analysis and GAMs. The data were fit using the SAS REG procedure for linear regression analysis and the SAS GAM procedure for nonparametric regression. The GAMs avoid the necessity of making assumptions relative to the form or shape of the relationships among variables. One disadvantage of GAMs is that they do not provide output for a model with established parameters, although predicted values and residuals can be obtained. After examining different values for degrees of freedom (df), we chose $4 \mathrm{df}$ in the models to allow for sufficient flexibility in shape without excessive data chasing. Growth rates for each species (IF data set) were fit to the model:

$\mathrm{G}_{\mathrm{i}}=$ spline (protein content, $\mathrm{df}=4$ ) spline (environmental variable, $\mathrm{df}=4$ )

where the environmental variable was either year day, photoperiod or temperature. A set of residual growth rates $\left(\mathrm{rG}_{\mathrm{i}}\right)$ was produced using photoperiod as the environmental variable. Photoperiod was selected over year day because of the importance of photoperiod to daily ration and to make the model more generally applicable to Atlantic cod and haddock populations occurring over a wide range of latitudes in the North Atlantic Ocean. Photoperiod was chosen over temperature since it explained slightly more of the observed variability in growth rate.

Stepwise linear regression analysis was completed on the IF data set using the model:

$$
\mathrm{G}_{\mathrm{i}}=\text { temperature photoperiod } \ln (\text { protein) }
$$

with forward selection. Correlation analysis was completed using the NM data set. The correlations between photoperiod and temperature, photoperiod and growth, and temperature and growth were used in path analysis for a 3 variable model (Pedhazur 1997). Path analysis is a special case of structural equation models. Since photoperiod can affect temperature but temperature cannot affect photoperiod, photoperiod was treated as an extrinsic variable and temperature was treated as an endogenous (dependent) variable.

Analysis of inter-annual variability. Statistical analysis of differences among years was limited to the years 1995, 1997 and 1999. This was done because effort and sample sizes were much greater during these years compared with either 1996 or 1998. Data for individual larvae containing $\leq 1200 \mu \mathrm{g}$ protein larva $^{-1}$ or $\sim 12 \mathrm{~mm} \mathrm{SSL} \mathrm{(IF} \mathrm{data} \mathrm{set)} \mathrm{were} \mathrm{fit} \mathrm{to} \mathrm{the}$ equation:

$$
\mathrm{G}_{\mathrm{i}}=\left[\mathrm{m}_{1} \times \ln (\text { Pro })\right]+\left[\mathrm{m}_{2} \times \mathrm{PP}\right]+\mathrm{C}
$$

where Pro is the protein content in $\mu g$ larva $^{-1}$, PP is the photoperiod in $h, m_{1}$ and $\mathrm{m}_{2}$ are regression coefficients and $\mathrm{C}$ is a constant. Separate equations were derived for each year. Daily growth curves for larvae hatched on April 1 (year day 91) of each year were then produced assuming exponential growth and a size at hatch of $23 \mu \mathrm{g}$ protein excluding yolk.

Following literature precedents (Ricker 1979, Campana \& Hurley 1989, Buckley et al. 2004) the relationship between recent growth and water temperature was fit to a quadratic parabola:

$$
\mathrm{G}_{\mathrm{i}}=\mathrm{G}_{\max }+\left[k \times\left(\mathrm{T}-\mathrm{T}_{\mathrm{opt}}\right)^{2}\right]
$$


where $G_{\max }$ is the maximum growth rate at the optimum water temperature for growth $\left(\mathrm{T}_{\mathrm{opt}}\right), k$ is always negative, and $\mathrm{T}$ is the temperature. Net means were used in the analysis (dataset NM).

Differences in growth rate among years were evaluated for lsc 2 and lsc 3 using ANOVA with the NMLSC data set. Both specific growth rate and $\mathrm{rG}_{\mathrm{i}}$ were considered. Growth residuals were used in part to control for the size of larvae and the timing of cruises that differed among years. The first model examined was:

$$
\mathrm{G}_{\mathrm{i}}=\text { month year lsc }
$$

with interactions. However, since there was no process cruise in March 1997 and due to significant interactions among main effects (year, month and lsc), separate analyses were run for each month and size class.

\section{RESULTS}

Sampling effort and consequently larval catches (Table 1) were greatest in the GLOBEC process-study years (1995, 1997 and 1999). Waters yielding larval Atlantic cod and haddock differed in temperature and salinity among the 3 primary sampling years. During April and May, mean water temperatures were highest in 1999 and lowest in 1997. Salinity was highest in 1995 and lowest in 1997. An examination of residual water temperature (rT) confirmed that 1997 was the coldest of the 3 process years and 1999 the warmest (during April and May).

Most larvae were collected in April and May, with April generally yielding more cod and May more haddock. All measures of larval size (length, RNA (not in table), DNA and protein content) were highly correlated $(\mathrm{R}>0.80)$ (Table 2). Since protein content can be reliably measured and is highly correlated with dry weight and length, protein content was used as a measure of larval size in all subsequent analyses. Protein accounts for about $50 \%$ of the dry weight in cod and haddock through their larval period (Buckley \& Lough 1987). Shipboard standard length in mm (measured from video images taken before preservation and not corrected for shrinkage) and protein content in $\mu \mathrm{g}$ pro-

Table 1. Melanogrammus aeglefinus and Gadus morhua. Summary data (mean $\pm 1 \mathrm{SD}$ ) for all larvae sampled for biochemistry between 1995 and 1999 with a protein content $\leq 1200 \mu \mathrm{g} . \mathrm{N}=$ the number of larvae collected and analyzed for RD, ND = no data, $\mathrm{PP}$ is photoperiod, and $\mathrm{rT}$ is the residual temperature

\begin{tabular}{|c|c|c|c|c|c|c|c|}
\hline & & $\mathrm{N}$ & PP (h) & $\mathrm{T}\left({ }^{\circ} \mathrm{C}\right)$ & $\mathrm{rT}\left({ }^{\circ} \mathrm{C}\right)$ & Salinity & Protein $(\mu g)$ \\
\hline \multicolumn{8}{|l|}{ March } \\
\hline \multirow[t]{5}{*}{ Haddock } & 1995 & 12 & $12.9 \pm 0.1$ & $4.9 \pm 0.1$ & $0.0 \pm 0.1$ & $32.8 \pm 0.1$ & $90 \pm 25$ \\
\hline & 1996 & ND & ND & ND & ND & ND & ND \\
\hline & 1997 & ND & ND & ND & ND & ND & ND \\
\hline & 1998 & ND & ND & ND & ND & ND & ND \\
\hline & 1999 & 131 & $13.1 \pm 0.1$ & $4.8 \pm 0.1$ & $-0.1 \pm 0.1$ & $32.6 \pm 0.0$ & $41 \pm 19$ \\
\hline \multirow[t]{5}{*}{ Cod } & 1995 & 116 & $13.0 \pm 0.1$ & $5.0 \pm 0.1$ & $0.1 \pm 0.1$ & $32.8 \pm 0.1$ & $94 \pm 114$ \\
\hline & 1996 & ND & ND & ND & ND & ND & ND \\
\hline & 1997 & ND & ND & ND & ND & ND & ND \\
\hline & 1998 & ND & ND & ND & ND & ND & ND \\
\hline & 1999 & 317 & $13.0 \pm 0.1$ & $4.8 \pm 0.0$ & $-0.1 \pm 0.0$ & $32.6 \pm 0.0$ & $76 \pm 48$ \\
\hline \multicolumn{8}{|l|}{ April } \\
\hline \multirow[t]{5}{*}{ Haddock } & 1995 & 398 & $14.3 \pm 0.2$ & $5.2 \pm 0.3$ & $-0.4 \pm 0.2$ & $32.7 \pm 0.1$ & $134 \pm 101$ \\
\hline & 1996 & 21 & $14.1 \pm 0.2$ & $4.9 \pm 0.2$ & $-0.6 \pm 0.2$ & $32.5 \pm 0.2$ & $180 \pm 165$ \\
\hline & 1997 & 746 & $14.0 \pm 0.2$ & $4.5 \pm 0.1$ & $-0.9 \pm 0.2$ & $32.2 \pm 0.0$ & $40 \pm 24$ \\
\hline & 1998 & ND & ND & ND & ND & ND & ND \\
\hline & 1999 & 1128 & $14.4 \pm 0.1$ & $5.9 \pm 0.2$ & $0.1 \pm 0.1$ & $32.6 \pm 0.1$ & $86 \pm 82$ \\
\hline \multirow[t]{5}{*}{ Cod } & 1995 & 1188 & $14.2 \pm 0.2$ & $5.2 \pm 0.3$ & $-0.4 \pm 0.2$ & $32.7 \pm 0.1$ & $156 \pm 90$ \\
\hline & 1996 & 251 & $14.2 \pm 0.2$ & $4.9 \pm 0.2$ & $-0.6 \pm 0.2$ & $32.5 \pm 0.2$ & $287 \pm 304$ \\
\hline & 1997 & 1112 & $14.0 \pm 0.2$ & $4.5 \pm 0.2$ & $-0.9 \pm 0.2$ & $32.2 \pm 0.1$ & $47 \pm 28$ \\
\hline & 1998 & ND & ND & ND & ND & ND & ND \\
\hline & 1999 & 1155 & $14.4 \pm 0.1$ & $5.9 \pm 0.2$ & $0.1 \pm 0.1$ & $32.6 \pm 0.1$ & $154 \pm 130$ \\
\hline \multicolumn{8}{|l|}{ May } \\
\hline \multirow[t]{5}{*}{ Haddock } & 1995 & 139 & $15.5 \pm 0.1$ & $6.9 \pm 0.7$ & $-0.5 \pm 0.5$ & $32.8 \pm 0.2$ & $194 \pm 156$ \\
\hline & 1996 & 52 & $15.3 \pm 0.0$ & $6.2 \pm 0.2$ & $-0.7 \pm 0.2$ & $32.5 \pm 0.1$ & $121 \pm 79$ \\
\hline & 1997 & 1087 & $15.4 \pm 0.1$ & $6.5 \pm 0.6$ & $-0.7 \pm 0.5$ & $32.3 \pm 0.1$ & $99 \pm 88$ \\
\hline & 1998 & 77 & $15.1 \pm 0.0$ & $6.9 \pm 0.4$ & $0.3 \pm 0.4$ & $32.0 \pm 0.0$ & $68 \pm 71$ \\
\hline & 1999 & 1651 & $15.5 \pm 0.2$ & $7.4 \pm 1.0$ & $0.0 \pm 1.0$ & $32.5 \pm 0.3$ & $294 \pm 222$ \\
\hline \multirow[t]{5}{*}{ Cod } & 1995 & 130 & $15.5 \pm 0.1$ & $6.8 \pm 0.4$ & $-0.5 \pm 0.3$ & $32.8 \pm 0.1$ & $386 \pm 347$ \\
\hline & 1996 & 140 & $15.3 \pm 0.1$ & $6.5 \pm 0.5$ & $-0.6 \pm 0.4$ & $32.4 \pm 0.1$ & $339 \pm 302$ \\
\hline & 1997 & 355 & $15.4 \pm 0.2$ & $6.6 \pm 0.5$ & $-0.6 \pm 0.4$ & $32.3 \pm 0.1$ & $139 \pm 118$ \\
\hline & 1998 & 169 & $15.1 \pm 0.0$ & $7.2 \pm 0.3$ & $0.5 \pm 0.3$ & $32.1 \pm 0.0$ & $102 \pm 55$ \\
\hline & 1999 & 881 & $15.5 \pm 0.2$ & $7.5 \pm 0.8$ & $0.1 \pm 0.8$ & $32.5 \pm 0.1$ & $350 \pm 247$ \\
\hline
\end{tabular}


tein larva ${ }^{-1}$ (Pro) were related according to the following equations:

$$
\begin{array}{ll}
\mathrm{SSL}_{\text {cod }}=1.308(\text { Pro })^{0.315} & \mathrm{n}=5920 \mathrm{R}^{2}=0.91 \\
\mathrm{SSL}_{\text {had }}=1.237(\text { Pro })^{0.324} & \mathrm{n}=5403 \mathrm{R}^{2}=0.92
\end{array}
$$

\section{Ontogenetic and seasonal trends}

Larval size, growth rate, year day of collection, photoperiod, water temperature and other environmental and biotic variables showed varying degrees of correlation (Table 2). Plots of recent growth rate on larval size (protein content) revealed a rapid initial increase in growth rate with larval size. This was followed by a more gradual increase in growth rate with size (Fig. 3a,b). The rapid initial increase in growth rate was sustained to a larger size in haddock than in cod. Among the environmental variables considered, growth rates of both cod and haddock showed the highest correlations with photoperiod and water temperature. Growth rate increased between March and
May with increasing photoperiod (Fig. 3c,d) and water temperature (not shown).

Two approaches were employed to develop seasonal models of growth rate that included the ontogenetic trend: stepwise linear regression and generalized additive models (GAMs). When larval size, as $\ln$ (Pro), water temperature and photoperiod were used in stepwise linear regressions with forward selection, the best 2-parameter models included photoperiod and larval size (Table 3). These size- and photoperiod-dependent growth (SPPDG) models explained $43 \%$ and $58 \%$ of the observed variability in growth rate of cod and haddock respectively. The SPPDG GAMs explained slightly more of the observed variability in growth rate of cod and haddock than did the linear models. Addition of water temperature to models that already contained Pro and PP terms removed little of the residual variability in larval growth. Two-parameter models with Pro and T explained slightly less of the observed variability in growth rate than did 2-parameter models with protein and photoperiod terms.

Table 2. Melanogrammus aeglefinus and Gadus morhua. Correlation matrix for environmental variables, size, biochemical composition and growth of larvae with a protein content $\leq 1200 \mu \mathrm{g}$ sampled between 1995 and 1999. Values are the correlation coefficient ( $R$, first row of each variable) and the probability ( $p$, second row of each variable) of a greater $R$ for net means (data set $\mathrm{NM}$ ). For $\operatorname{cod} \mathrm{N}=657$ and for haddock $\mathrm{N}=575$. DNA and protein content were expressed as $\mu g$ per larva

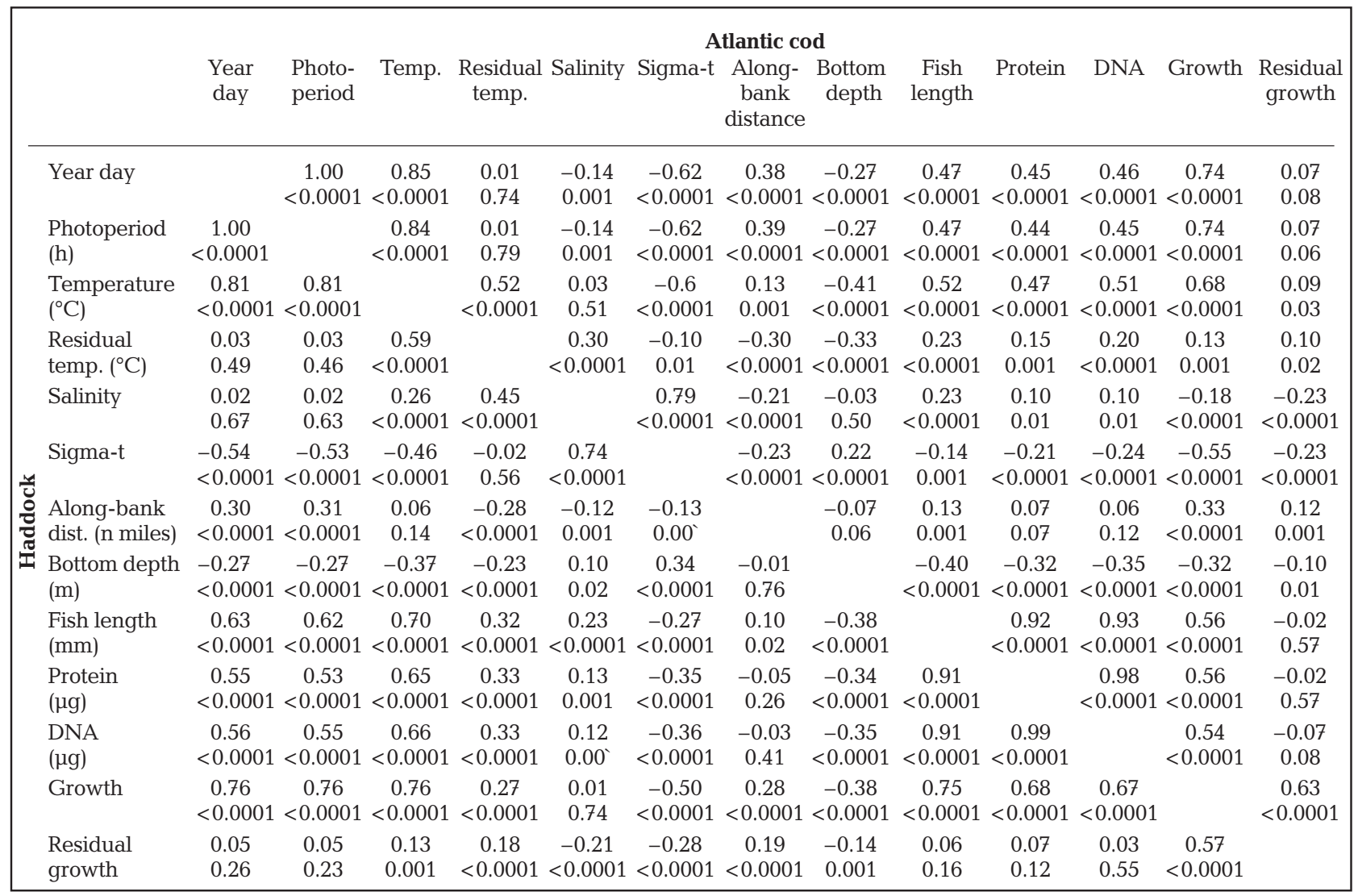



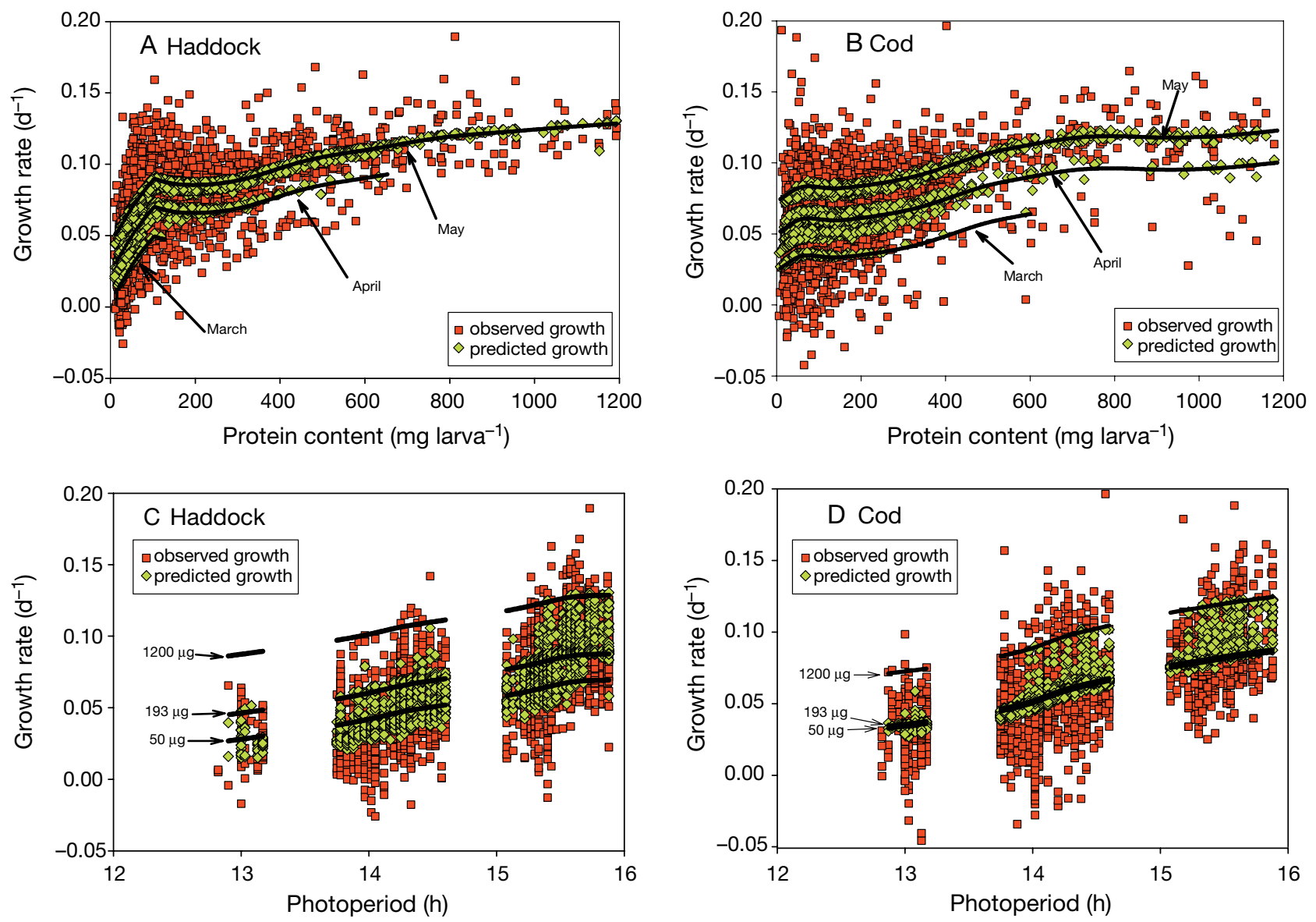

Fig. 3. Melanogrammus aeglefinus and Gadus morhua. Relationship between recent growth rate $\left(\mathrm{G}_{\mathrm{i}}\right)$, larval size measured as protein content $\left(\mu \mathrm{g} \mathrm{larva}^{-1}\right)$ and photoperiod $(\mathrm{h})$ : $(\mathrm{A})$ observed and predicted $\mathrm{G}_{\mathrm{i}}$ of haddock versus size; (B) observed and predicted $G_{i}$ of cod versus size; $(C)$ observed and predicted $G_{i}$ of haddock versus photoperiod; (D) observed and predicted $G_{i}$ of cod versus photoperiod. Predicted values are from size- and photoperiod-dependent growth dependent SPPDG GAMs. The 3 curves in $A$ and $B$ are predicted $G_{i}$ for larvae on March 15 (12.8 h PP), April 15 (14.3 h PP) and May 15 (15.5 h PP). The 3 curves in C and $\mathrm{D}$ are the predicted $\mathrm{G}_{\mathrm{i}}$ for larvae with protein content equal to the size thresholds for the 3 larval size classes (50, 193 and $1200 \mu \mathrm{g}$ protein). For presentation clarity the data were randomly sampled and $50 \%$ of available points plotted

Plots of predicted growth rate from the SPPDG GAMs followed closely the observed pattern of rapid initial increase in growth rates with size (Fig. 3a,b). The 3 curves illustrated correspond to the photoperiod on March 15 (12.8 h), April 15 (14.3 h) and May $15(15.5 \mathrm{~h})$. When predicted growth rates are plotted against photoperiod, the range of predicted values for any given photoperiod corresponds to larval size. Larvae with protein content corresponding to the cutoff points for the different size classes (50, 193 and $1200 \mu \mathrm{g})$ are shown. Again, the predicted values closely follow the observed trend of increasing growth rate with increasing photoperiod (Fig. 3c,d). The SPPDG GAMs fit to the IF data set were used to output an estimate of residual growth rate $\left(\mathrm{rG}_{\mathrm{i}}\right)$ of each larva, which represented the difference between the observed growth rate and that predicted on the basis of larval size and photoperiod on the day of capture.

To further explore the effects of photoperiod and temperature on larval growth rate we estimated path coefficients for the 3-variable (PP, $T$, and $\mathrm{G}_{\mathrm{i}}$ ) causal model illustrated in Fig. 4. For haddock, the direct effects of PP and $\mathrm{T}$ on larval growth rate were approximately equal $\left(p_{31}=p_{32}=0.42\right)$. For cod the direct effect of $\mathrm{PP}\left(p_{31}=\right.$ $0.57)$ was considerably greater than that of $\mathrm{T}\left(p_{32}=0.20\right)$. If both PP and T are treated as correlated exogenous variables our estimates of direct effects remain unchanged. However, when $\mathrm{T}$ is treated as an endogenous variable, as in Fig. 4, PP is considered to have an additional indirect effect $\left(p_{21} \times p_{23}\right)$ acting through $\mathrm{T}$. In this model the total effect of PP on $\mathrm{G}_{\mathrm{i}}$ is the sum of the direct and the indirect effects $\left[\mathrm{r}_{31}=p_{31}+\left(p_{21} \times p_{23}\right)\right]$, while the total effect of $\mathrm{T}$ is simply the direct effect $\left(\mathrm{r}_{32}=p_{32}\right)$. 
Table 3. (A) Melanogrammus aeglefinus and (B) Gadus morhua. Models relating larval growth to larval protein content, photoperiod, and temperature for the years 1995 through 1999. Data are observations for individual larvae (data set IF) with protein content $\leq 1200 \mu \mathrm{g}$ per larva. Pro is protein content in $\mu \mathrm{g}$ per larva and $\ln$ (Pro) the natural log of Pro; PP is the photoperiod (h); T is the temperature in ${ }^{\circ} \mathrm{C}$. The $\mathrm{R}^{2}$ values reported for the generalized additive models (GAMs) are for a linear relationship between observed and predicted values for growth. For all models, the probability of a greater $F$ value is $<0.0001$ and all variables are significant at $\mathrm{p}<0.0001$

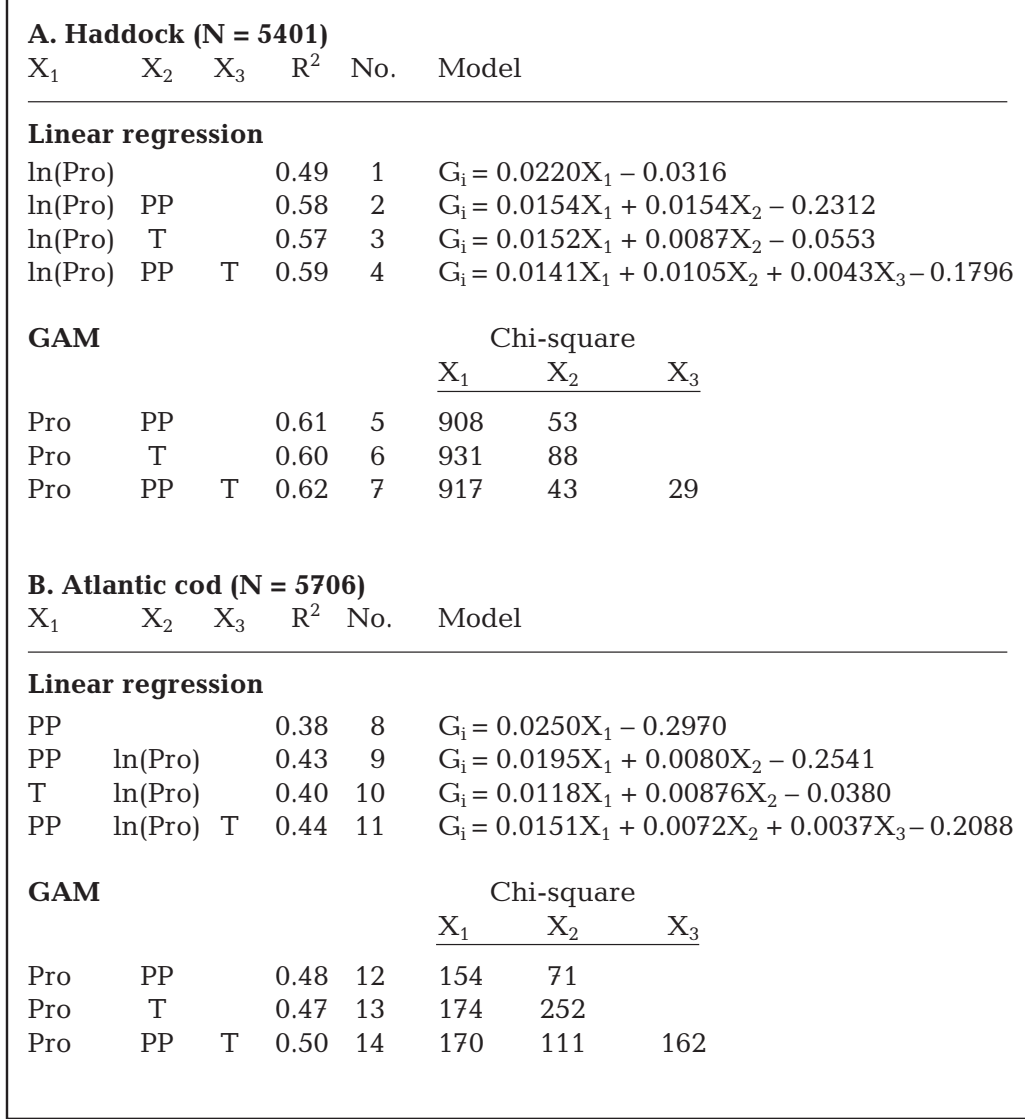

\section{Inter-annual differences in R:D growth and residual growth}

Size class 1 (yolk-sac and first feeding larvae)

We used the criteria outlined in Caldarone et al. (2003) and Caldarone (2005) to identify YSFF Atlantic cod and haddock larvae in starving condition (protein $\leq 50 \mu \mathrm{g}$ protein and R:D < 2.5). Of a total 1358 lsc 1 cod larvae collected between 1995 and 1999, only 67 (4.9\%) had R:D < 2.5. Of a total of 1678 lsc 1 haddock larvae collected between 1995 and 1999, only 144 (8.6\%) had $\mathrm{R}: \mathrm{D}<2.5$. Assuming that starved larvae live on average about $4 \mathrm{~d}$ after their R:D falls below 2.5 (Caldarone et al. 2003), starvation mortality of lsc 1 larvae was estimated at $1.2 \% \mathrm{~d}^{-1}$ in cod and $2.2 \% \mathrm{~d}^{-1}$ in haddock.

Large numbers of both cod and haddock YSFF larvae were collected in April of the process-study years (1995, 1997 and 1999), which afforded the opportunity to examine larval condition without the possibly confounding effect of season. The prevalence of starving lsc 1 larvae was highest in April 1995 at $19.5 \%$ and $36 \%$ for cod and haddock, respectively (Fig. 5), which corresponded to starvation mortality rates of $4.9 \% \mathrm{~d}^{-1}$ and $9.0 \% \mathrm{~d}^{-1}$ respectively. This is in contrast to the considerably lower prevalence of
A. Haddock

Photoperiod

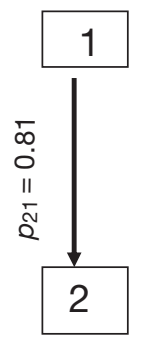

Temperature
B. Cod

Photoperiod
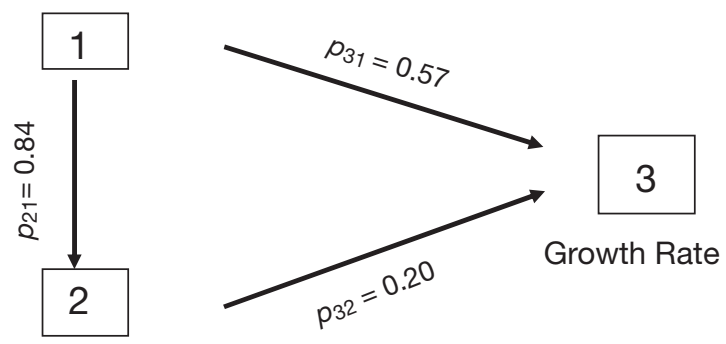

Temperature

Fig. 4. Melanogrammus aeglefinus and Gadus morhua. Causal models with path coefficients for the relationships among photoperiod, temperature and growth rate of (A) larval haddock and (B) cod. Photoperiod is considered an exogenous variable while temperature and growth rate are considered endogenous variables. Photoperiod is considered to affect temperature 

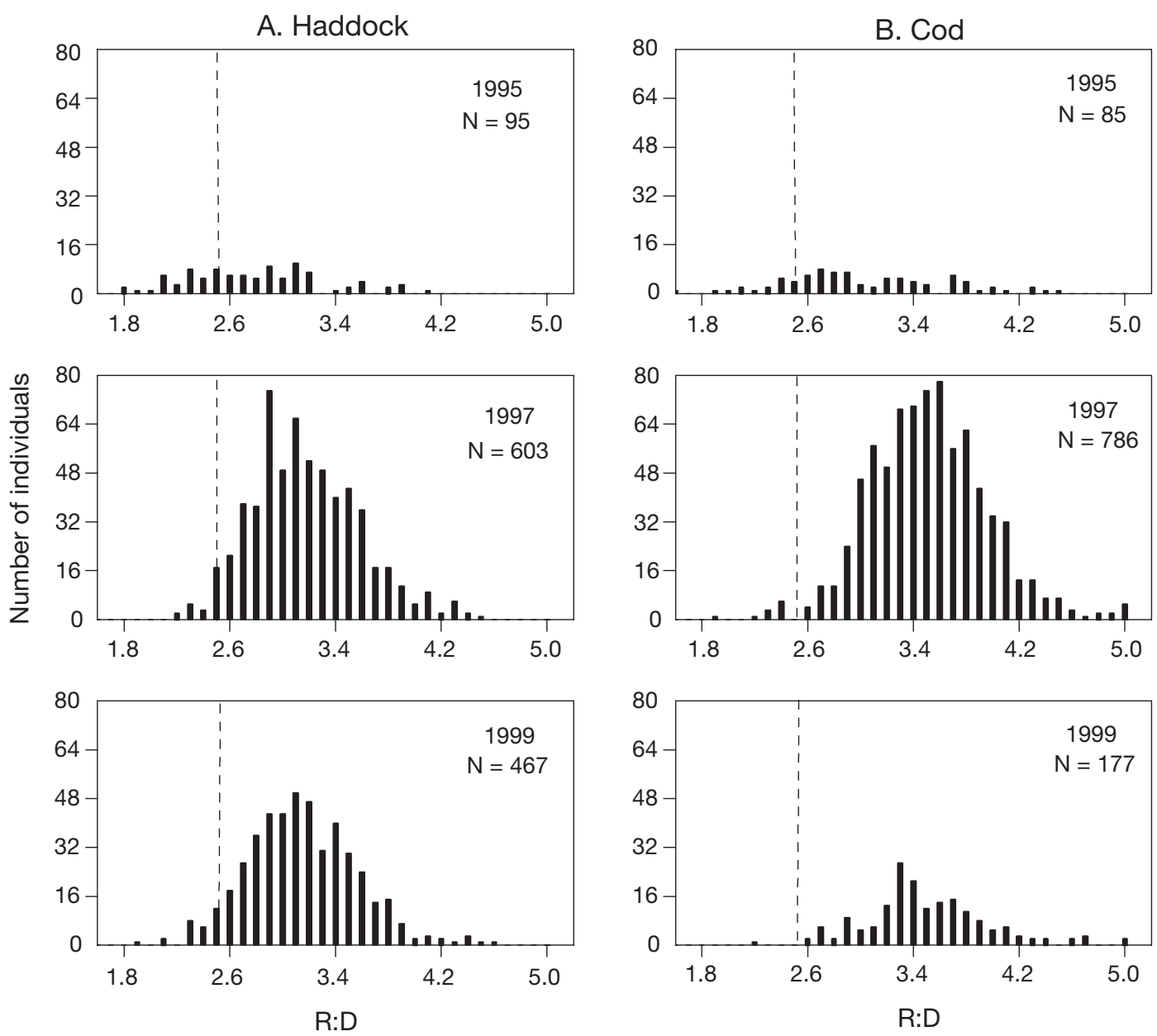

Fig. 5. Melanogrammus aeglefinus and Gadus morhua. Frequency distributions of RNA:DNA ratios for individual newly hatched (size class 1) (A) haddock and (B) cod larvae in April of 1995, 1997 and 1999. The vertical line shows the cutoff for starving larvae at 2.5

starving larvae observed in April 1997 (1.4\% and 4.5\% for cod and haddock, respectively) and in April 1999 $(0.5 \%$ and $6.2 \%$ for cod and haddock, respectively). Starvation mortality rates for lsc 1 larvae were $0.3 \%$ $\mathrm{d}^{-1}$ and $1.1 \% \mathrm{~d}^{-1}$ in April 1997 for cod and haddock and $0.1 \% \mathrm{~d}^{-1}$ and $1.6 \% \mathrm{~d}^{-1}$ in April 1999 for cod and haddock, respectively. At this stage, haddock appeared to be more susceptible to starvation than cod. In all instances larvae in starving condition were not concentrated in 1 or 2 locations, but scattered over much of the southern flank

\section{Size classes 2 and 3}

Differences in growth among years were evaluated in terms of both $\mathrm{G}_{\mathrm{i}}$ and $\mathrm{rG}_{\mathrm{i}}$ using the NMLSC data set. Growth residuals were used in part to control for the size of larvae and the timing of cruises, which differed among years. Data for all 5 years are shown in Table 4; however, statistical analysis was limited to the years 1995, 1997 and 1999 when we had good coverage on the process cruises. Since there was no process cruise in March 1997 and due to interactions among main effects (year, month and larval size class), separate analyses were run for each month and size class. Larval cod and haddock in both size classes generally grew fastest in 1997 and 1999, and slowest in 1995. These differences were most often significant for lsc 2 . Growth of lsc 3 tended to be more similar among years than that of lsc 2. Residual growth rates followed a similar trend. Without exception, mean $\mathrm{rG}_{\mathrm{i}}$ was consistently negative in 1995. In agreement with the results for YSFF larvae, growth conditions appeared particularly poor for the smaller size classes of larvae in 1995.

Linear SPPDG models were fit separately for each year using the IF data set. These models explained 
Table 4. Melanogrammus aeglefinus and Gadus morhua. Growth rate and residual growth rate $\left(\mathrm{rG}_{\mathrm{i}}\right)$ for larvae by size class $(2$ or 3$)$, month and year. Data are net means \pm SD for each size class (data set NMLSC). $N=$ no. of nets containing fish of a particular size class, $\mathrm{ND}=$ no data. Values in a row with a superscript letter in common are not significantly different (ANOVA models: growth rate = year; $\mathrm{rG}_{\mathrm{i}}=$ residual temperature, year). $\mathrm{rG}_{\mathrm{i}}$ is the difference between observed growth rate and growth rate predicted using SPPDG GAMs . Residual temperature is the difference between observed and long-term mean temperature for a given year day. Values for 1996 and 1998 are shown but not included in the statistical analysis due to the lower sampling effort

\begin{tabular}{|c|c|c|c|c|c|c|c|c|c|c|c|c|c|}
\hline \multirow{2}{*}{\multicolumn{2}{|c|}{$\begin{array}{r}\text { Month Size } \\
\text { class }\end{array}$}} & \multicolumn{2}{|c|}{-Model一 } & \multicolumn{2}{|c|}{$-1995-$} & \multicolumn{2}{|c|}{$-1997-$} & \multicolumn{2}{|c|}{$-1999-$} & \multicolumn{2}{|c|}{$-1996-$} & \multicolumn{2}{|c|}{$-1998-$} \\
\hline & & $\mathrm{r}^{2}$ & $\mathrm{p}>F$ & $\mathrm{~N}$ & Mean \pm SD & $\mathrm{N}$ & Mean \pm SD & $\mathrm{N}$ & Mean \pm SD & $\mathrm{N}$ & Mean \pm SD & $\mathrm{N}$ & Mean \pm SD \\
\hline \multicolumn{14}{|c|}{ Growth rate } \\
\hline \multicolumn{14}{|c|}{ Haddock } \\
\hline March & 2 & 0.44 & 0.0190 & 3 & $0.012^{b} \pm 0.029$ & ND & ND & 9 & $0.040^{\mathrm{a}} \pm 0.008$ & ND & ND & ND & ND \\
\hline \multirow[t]{2}{*}{ April } & 2 & 0.22 & $<0.0001$ & 60 & $0.050^{\mathrm{b}} \pm 0.021$ & 43 & $0.067^{a} \pm 0.016$ & 75 & $0.068^{a} \pm 0.011$ & 2 & $0.060 \pm 0.017$ & ND & ND \\
\hline & 3 & 0.07 & 0.0649 & 43 & $0.066^{\mathrm{a}} \pm 0.018$ & 2 & $0.079^{\mathrm{a}} \pm 0.009$ & 35 & $0.076^{\mathrm{a}} \pm 0.020$ & 2 & $0.101 \pm 0.010$ & ND & ND \\
\hline \multirow[t]{2}{*}{ May } & 2 & 0.14 & $<0.0001$ & 35 & $0.068^{\mathrm{C}} \pm 0.019$ & 114 & $0.087^{\mathrm{a}} \pm 0.017$ & 115 & $0.078^{\mathrm{b}} \pm 0.011$ & 10 & $0.066 \pm 0.018$ & 7 & $0.075 \pm 0.007$ \\
\hline & 3 & 0.06 & 0.0014 & 30 & $0.082^{\mathrm{b}} \pm 0.023$ & 42 & $0.097^{a} \pm 0.015$ & 129 & $0.093^{a} \pm 0.016$ & 5 & $0.086 \pm 0.017$ & 4 & $0.086 \pm 0.005$ \\
\hline \multicolumn{14}{|l|}{ Cod } \\
\hline \multirow{2}{*}{ March } & 2 & 0.39 & 0.0003 & 16 & $0.012^{\mathrm{b}} \pm 0.027$ & ND & ND & 13 & $0.044^{\mathrm{a}} \pm 0.006$ & ND & ND & ND & ND \\
\hline & 3 & 0.28 & 0.0748 & 6 & $0.027^{a} \pm 0.026$ & ND & ND & 6 & $0.049^{a} \pm 0.008$ & ND & ND & ND & ND \\
\hline \multirow[t]{2}{*}{ April } & 2 & 0.17 & $<0.0001$ & 120 & $0.049^{\mathrm{b}} \pm 0.024$ & 67 & $0.067^{\mathrm{a}} \pm 0.015$ & 75 & $0.066^{\mathrm{a}} \pm 0.008$ & 11 & $0.049 \pm 0.010$ & ND & ND \\
\hline & 3 & 0.19 & $<0.0001$ & 105 & $0.058^{\mathrm{a}} \pm 0.023$ & 2 & $0.062^{\mathrm{a}} \pm 0.001$ & 62 & $0.079^{\mathrm{a}} \pm 0.016$ & 21 & $0.074 \pm 0.020$ & ND & ND \\
\hline \multirow[t]{2}{*}{ May } & 2 & 0.08 & 0.0004 & 39 & $0.075^{\mathrm{b}} \pm 0.018$ & 66 & $0.086^{a} \pm 0.015$ & 80 & $0.079^{\mathrm{b}} \pm 0.011$ & 16 & $0.070 \pm 0.028$ & 9 & $0.088 \pm 0.006$ \\
\hline & 3 & 0.05 & 0.0173 & 29 & $0.098^{\mathrm{a}} \pm 0.025$ & 32 & $0.088^{\mathrm{b}} \pm 0.010$ & 109 & $0.098^{\mathrm{a}} \pm 0.017$ & 18 & $0.091 \pm 0.017$ & 6 & $0.088 \pm 0.008$ \\
\hline \multicolumn{14}{|c|}{ Residual growth rate } \\
\hline \multicolumn{14}{|c|}{ Haddock } \\
\hline March & 2 & 0.68 & 0.0010 & 3 & $-0.033^{\mathrm{b}} \pm 0.021$ & ND & ND & 9 & $0.003^{\mathrm{a}} \pm 0.008$ & ND & ND & ND & ND \\
\hline \multirow[t]{2}{*}{ April } & 2 & 0.36 & $<0.0001$ & 60 & $-0.013^{\mathrm{c}} \pm 0.019$ & 43 & $0.014^{a} \pm 0.014$ & 75 & $0.004^{b} \pm 0.010$ & 2 & $-0.001 \pm 0.016$ & ND & ND \\
\hline & 3 & 0.04 & 0.2198 & 43 & $-0.002^{\mathrm{a}} \pm 0.018$ & 2 & $0.013^{\mathrm{a}} \pm 0.012$ & 35 & $0.004^{\mathrm{a}} \pm 0.019$ & 2 & $0.028 \pm 0.003$ & ND & ND \\
\hline \multirow[t]{2}{*}{ May } & 2 & 0.27 & $<0.0001$ & 27 & $-0.014^{\mathrm{c}} \pm 0.016$ & 114 & $0.008^{\mathrm{a}} \pm 0.015$ & 115 & $-0.007^{\mathrm{b}} \pm 0.011$ & 10 & $-0.013 \pm 0.018$ & 7 & $0.002 \pm 0.006$ \\
\hline & 3 & 0.12 & $<0.0001$ & 27 & $-0.009^{\mathrm{c}} \pm 0.016$ & 42 & $0.007^{a} \pm 0.016$ & 129 & $-0.002^{\mathrm{b}} \pm 0.011$ & 5 & $0.003 \pm 0.017$ & 4 & $0.002 \pm 0.013$ \\
\hline \multicolumn{14}{|l|}{ Cod } \\
\hline \multirow[t]{2}{*}{ March } & 2 & 0.34 & 0.0012 & 15 & $-0.025^{b} \pm 0.033$ & ND & ND & 13 & $0.009^{\mathrm{a}} \pm 0.005$ & ND & ND & ND & ND \\
\hline & 3 & 0.32 & 0.0572 & 6 & $-0.018^{\mathrm{a}} \pm 0.033$ & ND & ND & 6 & $0.012^{\mathrm{a}} \pm 0.007$ & ND & ND & ND & ND \\
\hline \multirow[t]{2}{*}{ April } & 2 & 0.25 & $<0.0001$ & 120 & $-0.009^{\mathrm{c}} \pm 0.022$ & 67 & $0.015^{\mathrm{a}} \pm 0.014$ & 75 & $0.003^{b} \pm 0.010$ & 11 & $-0.008 \pm 0.007$ & ND & ND \\
\hline & 3 & 0.09 & 0.0004 & 103 & $-0.003^{\mathrm{a}} \pm 0.020$ & 2 & $0.013^{\mathrm{a}} \pm 0.004$ & 62 & $0.008^{\mathrm{a}} \pm 0.013$ & 21 & $-0.009 \pm 0.020$ & ND & ND \\
\hline \multirow[t]{2}{*}{ May } & 2 & 0.11 & $<0.0001$ & 26 & $-0.006^{\mathrm{b}} \pm 0.012$ & 66 & $0.005^{\mathrm{a}} \pm 0.014$ & 80 & $-0.004^{\mathrm{b}} \pm 0.011$ & 16 & $-0.009 \pm 0.028$ & 9 & $0.010 \pm 0.006$ \\
\hline & 3 & 0.11 & 0.4041 & 25 & $-0.004^{\mathrm{a}} \pm 0.017$ & 32 & $-0.002^{\mathrm{a}} \pm 0.010$ & 109 & $-0.001^{\mathrm{a}} \pm 0.011$ & 18 & $-0.009 \pm 0.012$ & 6 & $0.008 \pm 0.008$ \\
\hline
\end{tabular}

between 37 and $64 \%$ of the observed variability in growth each year (Table 5). The best model fits were observed in 1999 and the poorest fits in 1995. Model fits were generally better for haddock than cod. When these SPPDG models were used to generate growth curves, large differences in size-at-age and age at metamorphosis (1200 $\mu \mathrm{g}$ protein) were predicted among years (Fig. 6). Size-at-age and age at metamorphosis predicted using these models depend upon the start date (year day of hatching) and initial larval protein content. Using a start date of April 1 and an initial protein content of $23 \mu \mathrm{g}$, age at metamorphosis (1200 $\mu \mathrm{g}$ protein, $12 \mathrm{~mm}$ SSL) ranged from $52 \mathrm{~d}$ in 1997 to $61 \mathrm{~d}$ in 1995.

When the growth rate and temperature data were fit to a quadratic parabola, the fitted parameters, $G_{\max }$ and $T_{\text {opt }}$, varied among years and were lowest in 1995 for both species (Table 6). The shape parameter $(k)$ was lowest in 1995 indicating that growth rates decreased more rapidly on either size of $\mathrm{T}_{\mathrm{opt}}$ compared with the other years.

\section{Explaining residual growth rates $\left(\mathrm{rG}_{\mathrm{i}}\right)$}

Salinity, sigma-t $(\sigma \mathrm{t})$, stratification $(\Delta \sigma \mathrm{t}), \mathrm{rT}$, alongbank distance, temperature, and bottom depth all explained small but significant portions of the variabil-

Table 5. Melanogrammus aeglefinus and Gadus morhua. Relationship among larval size, photoperiod and recent growth rate of cod and haddock larvae fit to a linear model. Data for individual larvae with $\leq 1200 \mu \mathrm{g}$ protein per larva (data set IF) were fit to the equation: $\mathrm{G}_{\mathrm{i}}=\mathrm{m}_{1} \times \ln ($ Pro $)+\mathrm{m}_{2} \times$ $\mathrm{PP}+\mathrm{C}$, where Pro is the protein content in $\mu \mathrm{g}$ per larva and $\mathrm{PP}$ is the photoperiod in $\mathrm{h}$

\begin{tabular}{|clrcccc|}
\hline & & $\mathrm{N}$ & $\mathrm{r}^{2}$ & $\mathrm{~m}_{1}$ & $\mathrm{~m}_{2}$ & $\mathrm{C}$ \\
\hline 1995 & Haddock & 504 & 0.45 & 0.0169 & 0.0182 & -0.2909 \\
& Cod & 1314 & 0.37 & 0.0112 & 0.0280 & -0.4021 \\
1997 & Haddock & 1831 & 0.61 & 0.0224 & 0.0166 & -0.2724 \\
& Cod & 1433 & 0.38 & 0.0113 & 0.0154 & -0.2024 \\
1999 & Haddock & 2908 & 0.64 & 0.0181 & 0.0080 & -0.1341 \\
& Cod & 2352 & 0.57 & 0.0135 & 0.0125 & -0.1768 \\
\hline
\end{tabular}


Table 6. Melanogrammus aeglefinus and Gadus morhua. The relationship between water temperature and recent growth rate of cod and haddock larvae fit to a quadratic parabola. Net means for larvae with $\leq 1200 \mu \mathrm{g}$ protein per larva (data set NM) were fit to the equation: $\mathrm{G}_{\mathrm{i}}=\mathrm{G}_{\max }+k\left(\mathrm{~T}-\mathrm{T}_{\mathrm{opt}}\right)^{2}$, where $\mathrm{G}_{\max }$ is the maximum growth rate at the optimum water temperature for growth $\left(\mathrm{T}_{\mathrm{opt}}\right), k$ is always negative, and $\mathrm{T}$ is the temperature

\begin{tabular}{|ccccccr|}
\hline & $\mathrm{N}$ & $\mathrm{r}^{2}$ & $\mathrm{G}_{\mathrm{max}}$ & $k$ & $\mathrm{~T}_{\text {opt }}$ \\
\hline 1995 & Haddock & 118 & 0.36 & 0.083 & -0.0058 & 7.73 \\
& Cod & 192 & 0.45 & 0.091 & -0.0104 & 7.27 \\
1997 & Haddock & 209 & 0.70 & 0.120 & -0.0021 & 10.75 \\
& Cod & 182 & 0.63 & 0.094 & -0.0038 & 7.74 \\
1999 & Haddock & 220 & 0.78 & 0.110 & -0.0031 & 9.93 \\
& Cod & 204 & 0.68 & 0.114 & -0.0023 & 10.35 \\
\hline
\end{tabular}

ity in residual growth rates $\left(\mathrm{rG}_{\mathrm{i}}\right)$ (Table 7$)$. Distance along the bank and bottom depth were more important for haddock than for Atlantic cod. Stratification was a significant factor for larval haddock but not for cod. The relationships for $\mathrm{rG}_{\mathrm{i}}$ and water temperature in both species and bottom depth in haddock during May were markedly nonlinear, as indicated by the better fit of the GAMs compared with linear models. The GAMs

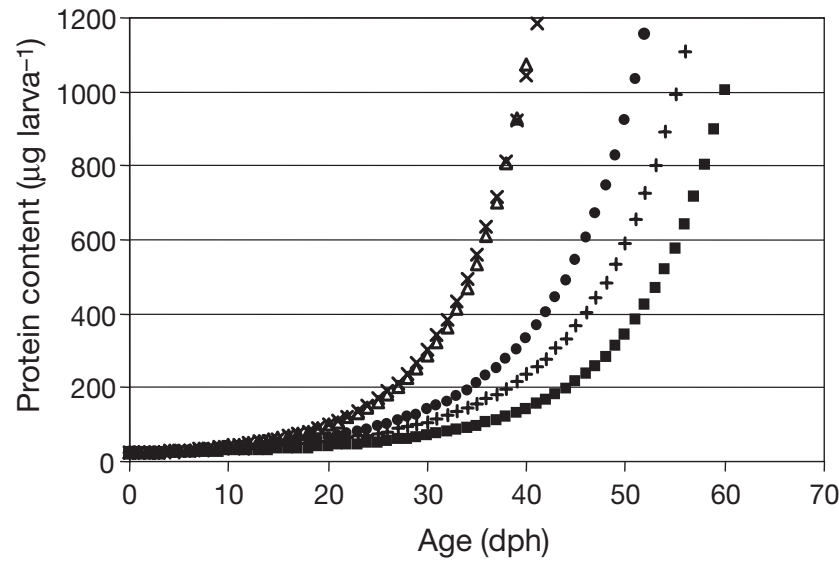

Fig. 6. Gadus morhua. Modeled growth of cod larvae on Georges Bank for the years 1995, 1997 and 1999. The curves for the years $1995(\boldsymbol{\bullet}), 1997(\bullet)$ and $1999(+)$ were estimated using the SPPDG models given in Table 6 , assuming a hatch size of $23 \mu \mathrm{g}$ protein on April 1. The curve for Folkvord's (2005) STDG model ( $x$ ) was generated using mean Georges Bank water temperatures for each year day. This curve was matched closely using our SPPDG model for 1999 when the longer photoperiods for Bergen, Norway $\left(60^{\circ} \mathrm{N}\right)$ were used $(\Delta)$. Dry weight was estimated as $2 \times$ the estimated protein content. The same April 1 hatch date was used for all curves

Table 7. Melanogrammus aeglefinus and Gadus morhua. Relationship between environmental variables and residual growth rate $\left(\mathrm{rG}_{\mathrm{i}}\right)$ for cod and haddock in size-classes 2 and $3 . \mathrm{N}$ is the number of nets containing size-class 2 larvae plus the number containing size-class 3 larvae (i.e. a net containing fish in both size classes constituted 2 observations). $\mathrm{N}=887$ for cod and 753 for haddock. The $\mathrm{R}^{2}$ and $\mathrm{p}>F$ values reported for GAMs are for a linear relationship between observed and predicted values, NS $=$ not significant. EDST is Eastern daylight savings time

\begin{tabular}{|c|c|c|c|c|c|c|c|}
\hline $\begin{array}{l}\text { Independent } \\
\text { variable }\end{array}$ & \multicolumn{3}{|c|}{ Linear models } & \multicolumn{4}{|c|}{ GAMS } \\
\hline \multicolumn{8}{|l|}{ Haddock } \\
\hline Salinity & 0.061 & $<0.0001$ & $\mathrm{rG}_{\mathrm{i}}=-0.0159 \mathrm{X}+0.5173$ & 31.7 & $<0.0001$ & 0.099 & $<0.0001$ \\
\hline Along-bank distance $(\mathrm{km})$ & 0.042 & $<0.0001$ & $\mathrm{rG}_{\mathrm{i}}=0.0002 \mathrm{X}-0.0136$ & 11.9 & $<0.05$ & 0.057 & $<0.0001$ \\
\hline Sigma-t & 0.048 & $<0.0001$ & $\mathrm{rG}_{\mathrm{i}}=-0.0149 \mathrm{X}+0.3795$ & 16.9 & $<0.01$ & 0.070 & $<0.0001$ \\
\hline Stratification & 0.007 & $<0.05$ & $\mathrm{rG}_{\mathrm{i}}=-0.0052 \mathrm{X}+0.0007$ & 12.5 & $<0.05$ & 0.026 & $<0.0001$ \\
\hline Bottom depth (m) & 0.011 & $<0.01$ & $\mathrm{rG}_{\mathrm{i}}=-0.0001 \mathrm{X}+0.0088$ & 6.7 & NS & & \\
\hline May only & 0.001 & NS & & 20 & $<0.001$ & 0.047 & $<0.0001$ \\
\hline Residual temp. $\left({ }^{\circ} \mathrm{C}\right)$ & 0.014 & $<0.001$ & $\mathrm{rG}_{\mathrm{i}}=0.0028 \mathrm{X}-0.0004$ & 11.5 & $<0.05$ & 0.030 & $<0.001$ \\
\hline 1999 only & 0.240 & $<0.0001$ & $\mathrm{rG}_{\mathrm{i}}=0.0082 \mathrm{X}-0.0014$ & 38.3 & $<0.0001$ & 0.320 & $<0.0001$ \\
\hline EDST $(\mathrm{h})$ & 0 & NS & & 9.7 & $<0.05$ & 0.014 & $<0.01$ \\
\hline Temperature $\left({ }^{\circ} \mathrm{C}\right)$ & 0 & NS & & 30.1 & $<0.0001$ & 0.042 & $<0.0001$ \\
\hline All of above & 0.196 & $<0.0001$ & & & & 0.280 & $<0.0001$ \\
\hline \multicolumn{8}{|l|}{ Atlantic cod } \\
\hline Salinity & 0.046 & $<0.0001$ & $\mathrm{rG}_{\mathrm{i}}=-0.0170 \mathrm{X}+0.5540$ & 17.2 & $<0.001$ & 0.065 & $<0.0001$ \\
\hline Along-bank distance (km) & 0.003 & NS & & 21.3 & $<0.001$ & 0.027 & $<0.0001$ \\
\hline Sigma-t & 0.033 & $<0.0001$ & $\mathrm{rG}_{\mathrm{i}}=-0.0128 \mathrm{X}+0.3258$ & 28.6 & $<0.0001$ & 0.066 & $<0.0001$ \\
\hline Stratification & 0.001 & NS & & 4.3 & NS & & \\
\hline Bottom depth (m) & 0.006 & $<0.05$ & $\mathrm{rG}_{\mathrm{i}}=-0.0001 \mathrm{X}+0.0060$ & 3.7 & NS & & \\
\hline May only & 0.006 & NS & & 9.1 & NS & & \\
\hline Residual temp. $\left({ }^{\circ} \mathrm{C}\right)$ & 0.011 & $<0.01$ & $\mathrm{rG}_{\mathrm{i}}=0.0033 \mathrm{X}$ & 23.1 & $<0.0001$ & 0.038 & $<0.0001$ \\
\hline 1999 only & 0.160 & $<0.0001$ & $\mathrm{rG}_{\mathrm{i}}=0.0081 \mathrm{X}-0.0009$ & 18.8 & $<0.001$ & 0.204 & $<0.0001$ \\
\hline Temperature $\left({ }^{\circ} \mathrm{C}\right)$ & 0.002 & NS & & 44.6 & $<0.0001$ & 0.064 & $<0.0001$ \\
\hline EDST (h) & 0.001 & NS & & 14.5 & $<0.01$ & 0.018 & $<0.0001$ \\
\hline All of above & 0.116 & $<0.0001$ & & & & 0.197 & $<0.0001$ \\
\hline
\end{tabular}




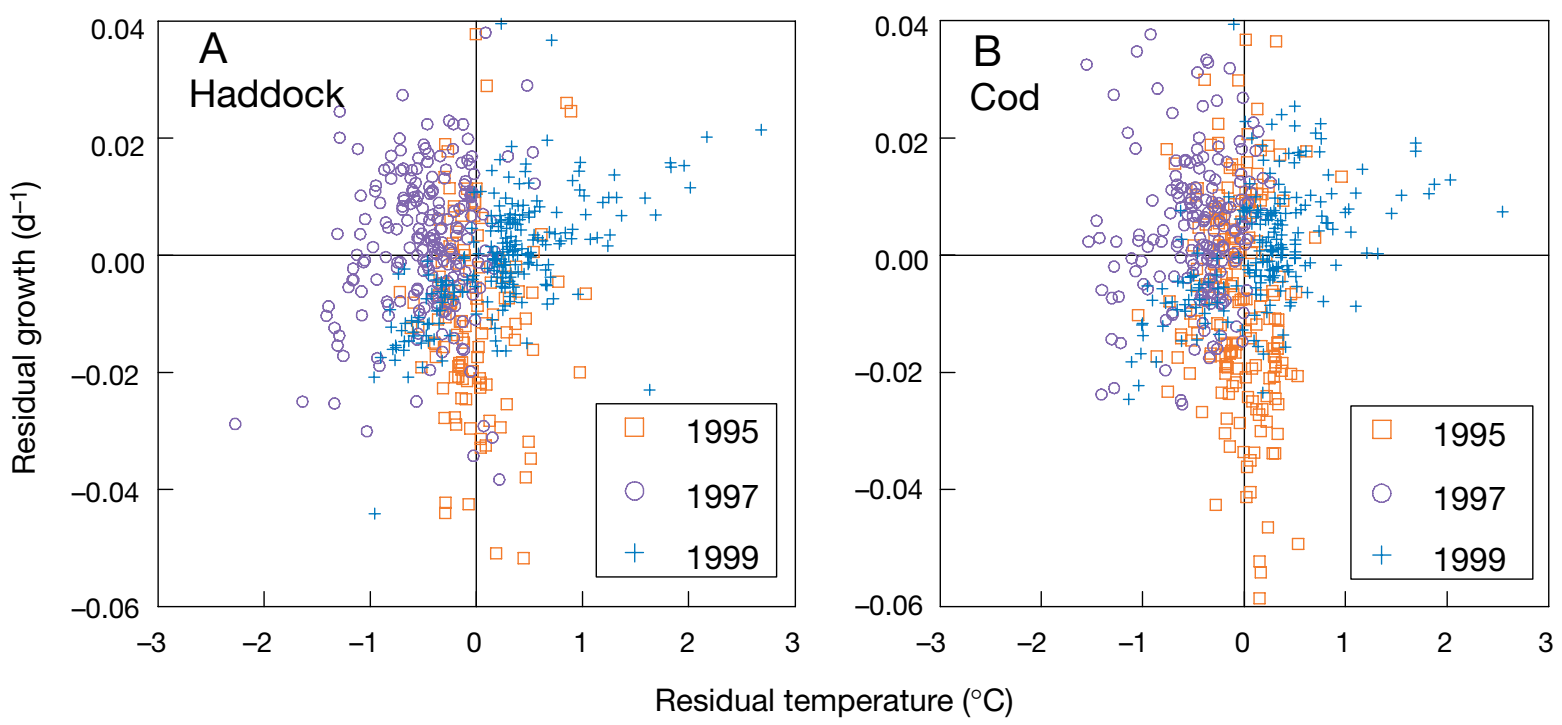

Fig. 7. Melanogrammus aeglefinus and Gadus morhua. Relationship between residual growth rate $\left(\mathrm{rG}_{\mathrm{i}}\right)$ and residual temperature in larval (A) haddock and (B) cod. $\mathrm{rG}_{\mathrm{i}}$ is the difference between observed growth rate and growth rate predicted by SPPDG GAMs

incorporating different combinations of these independent variables explained up to $28 \%$ of the variability in $\mathrm{rG}_{\mathrm{i}}$ for haddock and up to $20 \%$ of the variability in $\mathrm{rG}_{\mathrm{i}}$ for cod. Plots of $\mathrm{rG}_{\mathrm{i}}$ against $\mathrm{rT}$ indicated a strong linear relationship in 1999 for both cod and haddock (Fig. 7).

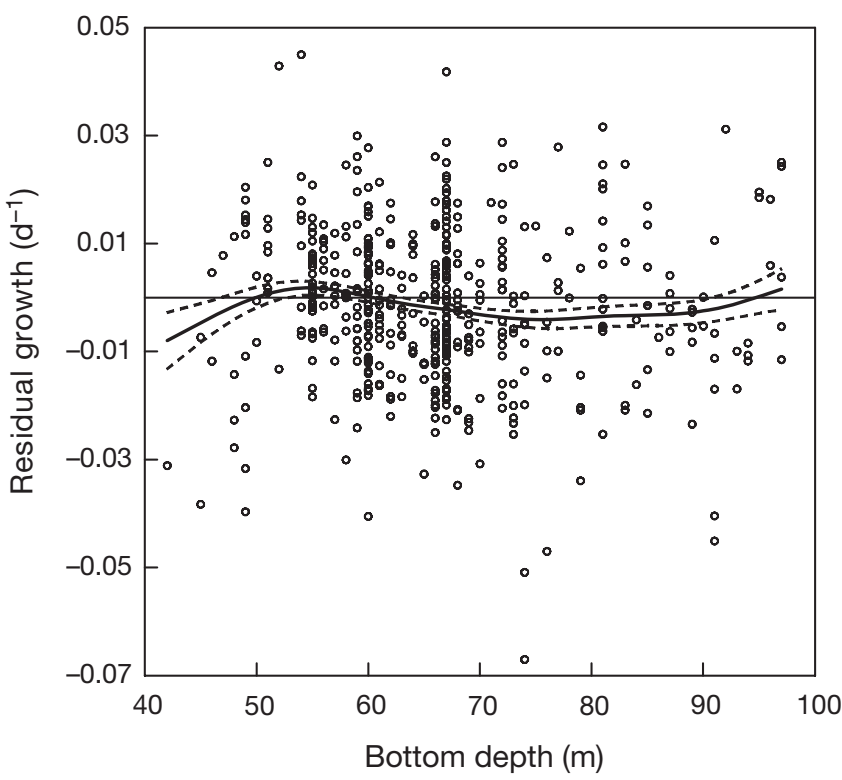

Fig. 8. Melanogrammus aeglefinus. Residual growth rate $\left(\mathrm{rG}_{\mathrm{i}}\right)$ for larval haddock versus bottom depth of sampling sites in May. $\mathrm{rG}_{\mathrm{i}}$ is the difference between observed growth rate and growth rate predicted by SPPDG GAMS. The solid curve represents the predicted value and the dashed curves are $\pm 1 \mathrm{SD}$ of the prediction
For 1999 , rT explained $24 \%$ and $16 \%$ of the variability in $\mathrm{rG}_{\mathrm{i}}$ for haddock and cod, respectively, using a linear model. No relationship between $\mathrm{rG}_{\mathrm{i}}$ and $\mathrm{rT}$ was apparent for either 1995 or 1997. Interestingly, the GAMs revealed local maxima in growth residuals when plotted against bottom depth for haddock in May (Fig. 8). The location of the maximum between the 50 and $60 \mathrm{~m}$ isobaths roughly corresponded to the location of the tidal-mixing front. More limited sampling at bottom depths $>90 \mathrm{~m}$ revealed a trend toward increasing growth residuals in the vicinity of the shelf-slope front. No strong pattern in $\mathrm{rG}_{\mathrm{i}}$ versus time of capture was apparent from visual inspection of the data (not shown). The GAMs with time of day as the independent variable and 4 degrees of freedom explained $<2 \%$ of the observed variability in $\mathrm{rG}_{\mathrm{i}}$.

\section{DISCUSSION}

Growth rates of both Atlantic cod and haddock on Georges Bank showed strong ontogenetic and seasonal trends, increasing dramatically with larval size and year day between March and May. But what factors are responsible for these trends and how can they best be modeled?

\section{Ontogenetic trends in larval growth rates}

Most marine fish larvae, including Atlantic cod and haddock, are relatively undifferentiated at hatching 
and development continues at a rapid rate through the first several weeks thereafter (Blaxter 1986). Within a species, developmental state is closely related to size. Houde (1997) examined the relation between weightspecific growth rate and size for a variety of marine and anadromous fish larvae and early juveniles. While numerous species exhibited increasing weight-specific growth rates during the first several weeks after hatching in culture, only 3 species (American shad Alosa sapidissima, striped bass Morone saxatilis and Pacific herring Clupea pallasii) showed a similar increase in growth rate with size in the sea. For striped bass and Pacific herring the relationship between weightspecific growth rate and size was dome-shaped. Houde (1997) concluded that for most marine species weightspecific growth rates in the sea were either relatively constant or declined with size during the larval period.

We found that larval size strongly affected growth rates of both cod and haddock larvae on Georges Bank. An initial rapid increase in growth rate was sustained to a size of about 80 to $106 \mu \mathrm{g}$ protein in cod and haddock respectively. Given the rapid development of visual, locomotive, respiratory and digestive systems that dramatically improve an individual larva's ability to acquire and process food in the first weeks after hatching (Hunter 1981, Blaxter 1986), an initial increase in growth rate with size would be expected. But why does weight-specific growth rate appear to decrease with larval size in most field studies? The methods and size groupings used may explain the differences in outcomes among studies. Most of the studies considered by Houde (1997) estimated lengthat-age based on counts of daily rings in the otoliths. Length-specific growth rates were estimated from these data and then converted to weight-specific rates using weight-length relationships. Larval shrinkage during capture and processing, variability in weightlength relationships, and underestimation of age in slow-growing individuals could contribute to error in estimating weight-specific growth rates using this approach. Data were then grouped into size categories and averaged to generate stage-specific information. In contrast, we treated larval size as a continuous variable and documented a very rapid initial increase in growth rate over a small range of size. This detail would have been lost in averaging within the size classes used by Houde (1997). Cod and haddock were among the species cited as showing an initial increase in growth rate with size in laboratory or enclosure studies but not in previous field studies, raising the possibility that increasing weight-specific growth rates during the larval period may be more common in the sea than previously thought.

Atlantic cod reared at high prey densities (Otterlei et al. 1999) showed a similar initial increase, as we found in weight-specific growth rates, that peaked at a size between 100 and $1000 \mu \mathrm{g}$ dry weight (depending upon the water temperature) and then declined. While it is certain that the rapid weight-specific growth rates seen in the middle and late larval periods are not sustained through the entire juvenile stage, the size at which growth rates begin to decline may vary depending upon a variety of factors including prey availability and quality, and any density-dependent effects. The inflection point where growth rates are maximum and then begin to decrease with size was not seen within the size range considered in our study $(<1200 \mu \mathrm{g}$ protein, $12 \mathrm{~mm}$ SSL). However, the curves representing growth rate were very flat for larger larvae suggesting that the inflection point was close to our threshold size near the transition from larvae to the juvenile stage.

In the sea, high mortality rates during the larval period likely contribute to the observed increase in growth rates with size (Meekan \& Fortier 1996, Pepin et al. 1999, Pitchford et al. 2005). Pepin et al. (1999) hypothesized that R:D and growth rate are indicators of survival probability (fitness) that are acquired early and remain somewhat persistent through a larva's life, and moreover that they contract toward the highest values with larval size due to selective mortality. High mortality would not have been a factor in at least some of the laboratory experiments where survival to the end of the experiments was high (Otterlei et al. 1999).

\section{Seasonal trends in larval growth rates}

Growth rate of Atlantic cod and haddock larvae on Georges Bank showed a strong seasonal trend increasing from March through May. During this period a number of environmental variables change on a similar pattern including temperature, photoperiod, and prey biomass concentration, and all likely play a role in determining larval growth rates.

Temperature affects the rate of chemical reactions. Because fish larvae are ectotherms, their activity and the rates of development, metabolism and digestion increase with temperature (Hunter 1981). In well-fed fish larvae, daily ration and growth rate increase with temperature and then fall precipitously as temperature approaches the lethal limit. However, when food is limited an increase in temperature can lead to a decreased growth rate, resulting in temperature optima $\left(\mathrm{T}_{\text {opt }}\right)$ for maximum growth $\left(\mathrm{G}_{\max }\right)$ lower than those observed for well-fed fish. Both $\mathrm{T}_{\text {opt }}$ and $\mathrm{G}_{\max }$ decrease with decreasing ration (Brett 1979). This is due to increased metabolic costs at the higher temperature that are not met by increased consumption in a foodpoor environment. 
In an earlier study we examined the relationship between water temperature and growth of larval cod and haddock in May on Georges Bank (Buckley et al. 2004). Based on 3 years of data (1992 to 1994), we reported a dome-shaped relationship between water temperature and recent growth rates of both species. Maximum growth was observed at temperatures near $7^{\circ} \mathrm{C}$, considerably lower than the 14 to $16^{\circ} \mathrm{C} \mathrm{T}_{\text {opt }}$ reported for well-fed cod larvae (Otterlei et al. 1999). Similar low $\mathrm{T}_{\text {opt }}$ values for larvae collected in the northwest Atlantic Ocean were reported earlier, based on otolith microstructure analysis (Campana \& Hurley 1989). The low $T_{\text {opt }}$ and $G_{\max }$ values, and the reduced growth at higher temperatures, compared with wellfed larvae in the laboratory, were offered as evidence for food-limited growth in larval cod and haddock.

The US GLOBEC Georges Bank Program provided the opportunity to examine, in much greater detail, the relations between larval growth and environmental variability over the period of larval drift. While the relationship between temperature and growth was variable among years, the data presented here also support the hypothesis that larval growth can at times be food-limited. The low $\mathrm{T}_{\text {opt }}$ values observed in 1995 for both cod and haddock were suggestive of foodlimited growth. The higher $\mathrm{T}_{\mathrm{opt}}$ values observed in 1997 and 1999 indicate that sufficient food was available in those years to support rapid larval growth. This conclusion also was supported by an analysis of the mean prey biomass concentration estimated for different size classes of cod from the monthly GLOBEC broadscale surveys (Buckley \& Durbin 2006).

Most marine fish larvae including cod and haddock are visual feeders (Hunter 1981, Blaxter 1986). Photoperiod determines the time available for feeding each day and consequently affects daily ration and growth rate (Suthers \& Sundby 1996). One assumption common to most larval bioenergetics models is that foraging time and consumption are directly proportional to photoperiod (e.g. Laurence 1985, Letcher et al. 1996, Lough et al. 2005). Increasing photoperiod from 12 to $18 \mathrm{~h}$ in these models results in $~ 50 \%$ increase in consumption and a comparable increase in growth rate. Puvanendran \& Brown (2002) reported that weightspecific growth rates of larval cod reared with abundant food at a constant temperature were $50 \%$ higher in the first 4 wk after hatching when kept on an $18 \mathrm{~h}$ photoperiod compared with a $12 \mathrm{~h}$ photoperiod. Growth rates further increased by another $20 \%$ when photoperiod was increased from 18 to $24 \mathrm{~h}$. Growth rates of herring Clupea harengus larvae in the laboratory at both high and low prey densities were almost $50 \%$ higher on a long spring photoperiod (16 to $20 \mathrm{~h}$ ) compared with a short fall photoperiod (13 to $10 \mathrm{~h}$ ) (Johannessen et al. 2000). Aquaculturists now rou- tinely rear cod and haddock larvae at temperatures above $10^{\circ} \mathrm{C}$ and photoperiods in excess of $16 \mathrm{~h}$ to take advantage of the rapid growth and high survival achieved under these conditions when food is available in excess (Baskerville-Bridges \& Kling 2000).

Food is a primary factor affecting larval growth, since without a source of energy and metabolites there is no growth. For a period of days after hatching the embryo continues to develop and grow using energy and metabolites stored in the yolk. Exogenous feeding must be initiated before maternal sources of energy are fully depleted. In culture, larval growth rates increase and mortality rates decrease with increasing prey levels (Houde 1978, Buckley et al. 1993). Although considerable debate still exists concerning the role of food availability in determining larval growth and mortality rates in the sea (Leggett \& Deblois 1994), there is a growing body of evidence suggesting that food can at times limit growth rates and affect mortality rates of marine fish larvae (e.g. Suthers et al. 1989, Bailey et al. 1995, Rilling \& Houde 1999, Buckley et al. 2004, Takahashi \& Watanabe 2005, Buckley \& Durbin 2006). At other times there appears to be more than sufficient prey available to saturate larval feeding (e.g. MacKenzie et al. 1990, Gallego et al. 1999, Baumann et al. 2003, Lough et al. 2005).

\section{Modeling the ontogenetic and seasonal trends in growth rates}

Larval size, measured as protein content, was highly correlated with growth rates of both Atlantic cod and haddock larvae. Because of its relatively constant proportion to dry weight and its structural role in muscle tissue, protein content was an obvious choice for an independent variable against which to model the ontogenetic trend in growth rates. The shape of the relationship between protein content and larval growth rate was less obvious since a number of curves fit the data reasonably well. The GAMs do not impose any particular shape and provide a tool to explore the relationships among variables. When fit to our data, GAMs revealed 3 apparent growth stanzas with relatively sharp transitions between the first and second stanza and a more gradual transition between the second and third stanza. The same general pattern was seen for both cod and haddock, and persisted when the data were grouped by month in an attempt to minimize the effects of factors related to the seasonal cycle. The first stanza was characterized by a rapid initial increase in growth rate with size. This was followed by a stanza characterized by little change in growth rate with size. The third stanza was characterized by a gradual increase in growth rate with size, approaching a maxi- 
mum growth rate. The transition point between the first and second stanza occurred at a larger size in haddock than in cod.

The choice of an independent variable or variables to model the seasonal trend in growth rates was not obvious. We considered 3 candidate variables (year day, photoperiod and temperature), all easily estimated or measured and all highly correlated with larval size and growth rates. The high correlations among these variables in the spring on Georges Bank suggested that they contain much of the same information. We presented a variety of growth models incorporating these variables, but for purposes of removing the ontogenetic and seasonal trends in growth rate and exploring the relationships among variables, we used SPPDG GAMs. For predictive purposes we used linear SPPDG models incorporating size as ln (protein content). We chose photoperiod over year day in order to produce models that were more generally applicable to other cod and haddock stocks that occur at widely different latitudes and spawn at different times of the year. Spawning time and latitude strongly affect the pattern of photoperiod experienced by different stocks during the larval period. Fall-spawned cod, for example, would experience a declining photoperiod during the larval period. We chose photoperiod over temperature due to its slightly higher correlation with larval growth rates, and other considerations discussed in the following section. Once photoperiod was incorporated into the models, temperature explained little of the residual variability in larval growth rates, except in 1999.

\section{Role of photoperiod and temperature in determining larval growth rates}

Laboratory experimental studies, bioenergetics considerations and examination of our data suggest that larval growth may be at least as responsive to photoperiod as water temperature. The increase in growth rate between March and May can be examined without the confounding effect of larval size by limiting consideration to a narrow size range. Each month, $7 \mathrm{~mm}$ cod larvae (6.5 to $7.5 \mathrm{~mm}$ SSL) were well represented in the catch. Growth rates of $7 \mathrm{~mm}$ larvae generally increased from March to May, with the greatest increase observed occurring between March and the end of April (Fig. 9). Water temperatures increased over this period from about $4^{\circ} \mathrm{C}$ to $8^{\circ} \mathrm{C}$. The greatest increase in water temperature occurred between April and May, coinciding with the onset of stratification in waters deeper than about $60 \mathrm{~m}$. Relatively few larvae were collected in waters warmer than $9^{\circ} \mathrm{C}$. At the latitude of Georges Bank, photoperiod increased during this period from about $12 \mathrm{~h}$ at the beginning of March to $16 \mathrm{~h}$ at the end of May; the greatest increase occurred during March and April, which better matched the trend seen in larval growth (Fig. 9). Based on the results of Puvanendran \& Brown (2002), this increase in photoperiod should result in about a $30 \%$ increase in growth rate in cod larvae.

Path analysis suggests that the direct effects of photoperiod and water temperature on larval growth rates are roughly equal for haddock larvae, while for cod the direct effect of photoperiod is considerably greater than that of temperature. If temperature is considered an endogenous variable affected by photoperiod, then photoperiod also has an indirect effect on growth rate acting through its effect on temperature. Thus, the total effect of photoperiod is the sum of both the direct and indirect effects. Temperature in this model has no indirect effect. This simple 3-parameter causal model is reasonable since at least some part of the spring increase in water temperature is due to increasing photoperiod, while temperature has no effect on photoperiod. Numerous additional variables could be
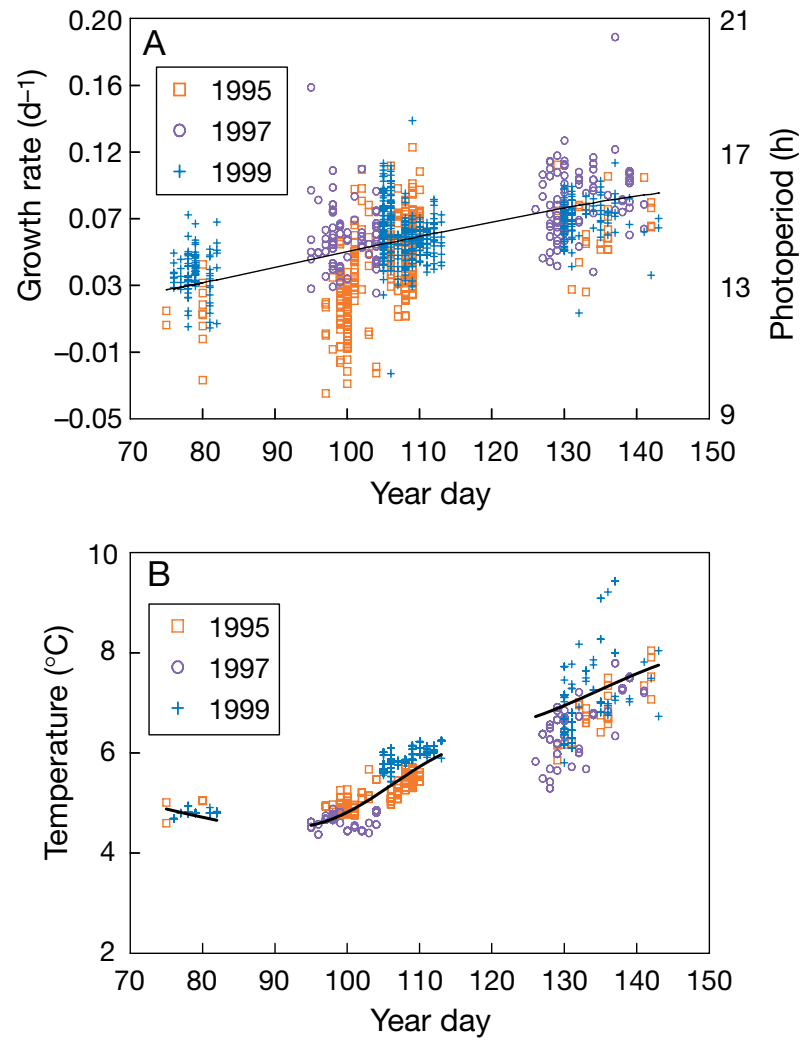

Fig. 9. Gadus morhua. Recent growth rate of $7 \mathrm{~mm}$ cod, photoperiod and water temperature versus year day: (A) observed growth rate (symbols) of $7 \mathrm{~mm}$ cod larvae and photoperiod (line); (B) observed (symbols) and predicted (line) water temperature. Predicted values for water temperature are from a GAM incorporating a year day term 
added to this simple causal model, but for the most part the data needed to establish parameters for these more complex causal models are not available. For example, both photoperiod and temperature affect food availability and both would have additional indirect effects acting through food availability.

Our SPPDG models explain much of the observed variability in growth rate without directly considering food availability. Certain variables such as water temperature, photoperiod, position in the water column and position in relation to a hydrographic front may be related to food availability (Heath \& Gallego 1997, Munk 1997) and serve to some extent as a proxy for food availability. On Georges Bank, photoperiod, water temperature, prey biomass concentration and larval growth rates follow similar trends in the late winter and spring during the period of larval drift (Buckley \& Durbin 2006). Our SPPDG models, without specific temperature and food availability terms, contain information on temperature and food availability due to their correlation with dependent variables used in the models. For Georges Bank, photoperiod rather than temperature appears to be the better predictor or proxy for the seasonal trend in feeding conditions and growth rates of larval cod and haddock.

Most often in field studies where increased larval growth rates are associated with increased water temperature, the increased growth rates are attributed to water temperature (Heath 1992). Often the increase in temperature is part of a seasonal cycle or associated with different water masses, and other environmental variables, such as photoperiod and prey abundance, change in concert with temperature (Sundby 2000). These other variables are often not considered to the same degree as water temperature. Photoperiod in particular has received relatively little attention in field studies. Two examples serve to illustrate this point. Xie \& Watanabe (2005) reported, based on otolith microstructure analysis, that rates of growth and development of jack mackerel Trachurus japonicus were higher in late-hatched compared with early-hatched fish. They concluded, 'higher water temperatures experienced by late-hatched fish during the early life stages may contribute critically to the higher growth and development rates.' Photoperiod was not considered in the paper; however, in the study area $\left(\sim 30^{\circ} \mathrm{N}\right)$ photoperiod increased over the study period from $11.6 \mathrm{~h}$ on February 1 to $14.4 \mathrm{~h}$ on June 1. This $24 \%$ increase in photoperiod could also have contributed to the higher growth and development rates observed in late-hatched fish. In another example, Gallego et al. (1999) concluded, 'Daily larval haddock growth variability, estimated from otolith microstructure analysis, was independent of the measured variability of the physical and biological environment of the larvae.'
Variables considered included temperature, turbulence, depth of the mixed layer, light intensity, chlorophyll and zooplankton concentrations. They determined that individual birth date was the only 'environmental' variable (their quote) that explained a significant portion of the observed variability in daily growth rates. However, they did not address the effect of birth date on the photoperiod experienced by larvae. In their North Sea study area $\left(\sim 60^{\circ} \mathrm{N}\right)$ in April, a difference in hatch date of only $10 \mathrm{~d}$ resulted in a $1 \mathrm{~h}$ difference in photoperiod.

Apart from the direct effects of photoperiod and temperature on larval growth rates, these variables serve as estimators of position in the seasonal cycle. Our estimates of photoperiod are based simply on date and latitude, while we used actual water temperature at the time of sampling. That the fixed variables (year day and photoperiod) showed correlations with growth rates as high or higher than that with actual water temperature implies that (1) the seasonal cycle on Georges Bank was relatively fixed in time for the 5 years (1995 to 1999) studied and (2) the position in the seasonal cycle was as important as actual water temperature in determining larval growth rates.

While the times of sunrise and sunset are a function of the day of the year and the latitude, light at depth and effective photoperiod can vary greatly depending on a variety of factors including cloud cover, fog, sea state and pigment concentration (Suthers \& Sundby 1996). These factors have their greatest effects at dawn and dusk when the sun is close to the horizon, and in the surface and deep waters where light levels are near their upper and lower limits for feeding. Estimates of the probability of clouds on the southern flank of Georges Bank based on SeaWiFS data (J. O'Riley pers comm) demonstrate considerable variability in the spring among both months and years. The resulting variability in incident energy and effective photoperiod may also play a role in explaining $\mathrm{rG}_{\mathrm{i}}$ and interannual variability in larval growth and survival.

\section{Comparison with other growth models}

Folkvord (2005) suggested 'that surviving cod larvae in the sea typically grow at rates close to their maximum size- and temperature-dependent capacity.' This maximum capacity was based on output from a sizeand temperature-dependent growth (STDG) model derived from laboratory experiments on Atlantic cod larvae reared at temperatures between 4 and $14^{\circ} \mathrm{C}$ and fed to satiation (Otterlei et al. 1999). The effect of temperature on growth was approximately linear in their underlying data. Photoperiod, although not explicitly stated in either paper or incorporated into the model, 
was relatively long and adjusted during the $56 \mathrm{~d}$ experiments to correspond with that at Bergen, Norway $\left(\sim 60^{\circ} \mathrm{N}\right)$ between April and the beginning of June. Folkvord (2005) limited his consideration of field data to published studies where growth was estimated from otolith microstructure analysis. His conclusions tended to minimize any effect of photoperiod and food availability in determining growth of surviving larvae in the sea. In contrast, our data showed variability in growth rates that cannot be explained solely by differences in temperature and larval size. Moreover, the data demonstrated the importance of photoperiod and food density in determining the growth rate of cod and haddock larvae in the sea.

Estimates of recent growth rates of larval Atlantic cod on Georges Bank based on R:D and temperature were on average lower than that predicted by Folkvord's (2005) STDG models (Fig. 10). This was particularly true for small larvae $(<400 \mu \mathrm{g}$ protein) and not unexpected, since his STDG models were based on larvae reared with abundant food at photoperiods considerably longer in Norway than those on Georges Bank $\left(\sim 41^{\circ} \mathrm{N}\right)$. The better agreement between Folkvord's (2005) reference growth rates and our observed growth rates for larger larvae may result from the selective mortality of slow growing larvae over time in the sea (Meekan \& Fortier 1996, Pepin et al. 1999, Nielsen \& Munk 2004). The persistent difference between our observations and the reference growth

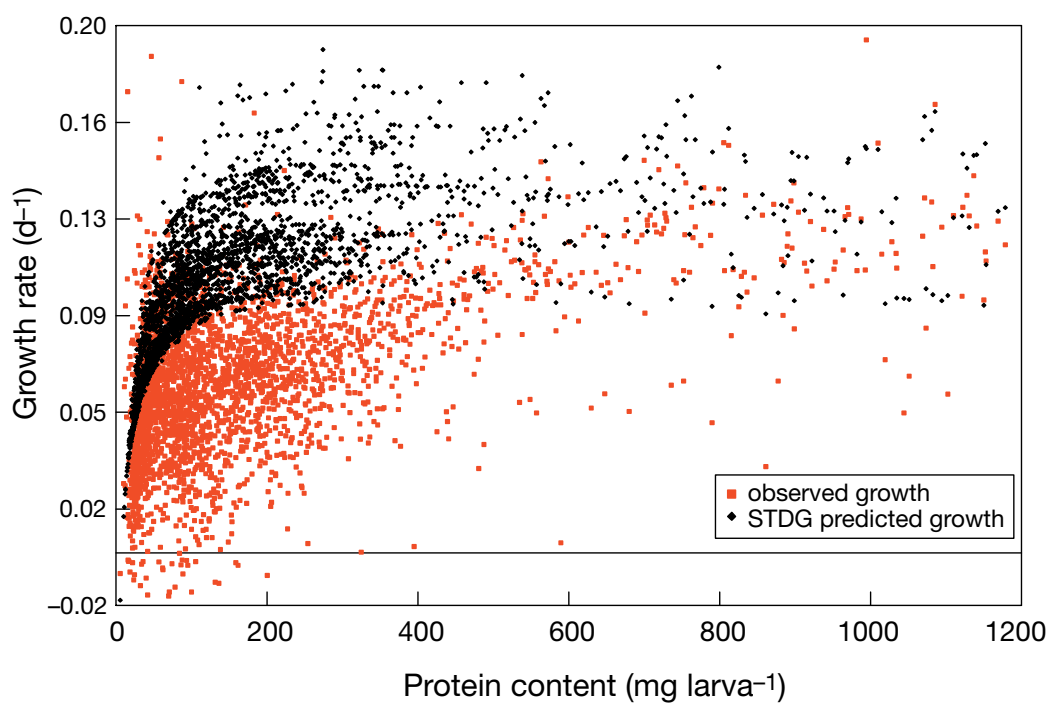

Fig. 10. Gadus morhua. Observed growth rates $\left(\mathrm{G}_{\mathrm{i}}\right)$ of individual cod larvae on Georges Bank and growth rates predicted using a STDG model developed for well-fed larvae in the laboratory versus larval protein content. Predicted growth rates were estimated using Folkvord's (2005) STDG model with observed temperature and protein content from Georges Bank. For presentation clarity the data were randomly sampled and $50 \%$ of available points plotted rates is likely due to differences between rearing conditions in Norway and ambient photoperiod and prey levels on Georges Bank. Predictions of size-at-age using Folkvord's STDG models with ambient Georges Bank temperatures and our SPPDG model converged (Fig. 6) when the longer photoperiods for Bergen, Norway were used in our SPPDG model instead of the shorter photoperiod for Georges Bank. This suggests that the 2 models are in good agreement when the effect of photoperiod is considered. A reference growth model for well-fed larvae that incorporates the effects of both temperature and photoperiod is needed to predict the maximum growth potential of larvae over the range of temperatures and photoperiods encountered in the sea.

Estimates of size-at-age of Georges Bank cod and haddock larvae based on our SPPDG models tend to be lower that those based on otolith daily-ring counts (Bolz \& Lough 1988, Green et al. 2004). A number of factors likely contribute to this difference. Some are methodological, such as correction for shrinkage, underestimation of age due to slow growth, and daily increment spacing in otoliths below the resolution of light microscopes (Folkvord 2005). Others reflect the biases of the 2 approaches. Estimates of size-at-age based on otolith ring counts reflect the population at the time of sampling, but estimates of growth rate based on these data are biased toward that of the largest and oldest larvae sampled, the survivors (Pitchford et al. 2005). Estimates of growth rate based on R:D analysis reflect that of the population at the time of sampling, but estimates of size-at-age based on these data are biased toward that of the population which includes many individuals that may not share characteristics (like rapid growth) with survivors.

\section{Interannual differences in growth rate}

A strong year effect on growth rate and residual growth rate $\left(\mathrm{rG}_{\mathrm{i}}\right)$ persisted in our models that incorporated larval size, photoperiod and residual temperature. This can be seen in the size-at-age curves based on SPPDG models fit to individual years (Fig. 6). The SPPDG models for 1995, 1997 and 1999 suggested that cod larvae hatching on April 1 and containing $23 \mu \mathrm{g}$ protein would require between $52 \mathrm{~d}$ (1997) and $61 \mathrm{~d}$ (1995) to reach metamorphosis (1200 $\mu \mathrm{g}$ of protein). Assuming a constant mortality rate of $0.08 \mathrm{~d}^{-1}$, this difference in 
development time would result in a 2-fold difference in survival to metamorphosis among years. Any sizeselective mortality (Meekan \& Fortier 1996) and variability in growth rates (Pitchford et al. 2005) would magnify this difference.

The year effect was consistent among months, suggesting that the factors responsible operated over extended periods of time (months). Food availability is the single additional factor (beyond larval size, photoperiod and temperature) most likely to explain the residual variability in observed larval growth and to account for the year effect. Food availability may also explain the different patterns seen in the T-G relationships among years and the particularly strong positive relationship observed between $\mathrm{rG}_{\mathrm{i}}$ and $\mathrm{rT}$ observed in 1999. An analysis of the prey available to cod and haddock larvae on Georges Bank for the years from 1995 to 1999 based on a series of standard stations sampled monthly suggested that prey concentrations increased during the period of larval drift (February to June), and were lower in 1995 and 1996 compared with the period from 1997 to 1999 (Buckley \& Durbin 2006). They reported a strong positive relationship between monthly average prey biomass concentration and growth rates of larval cod and haddock. Residual growth rates increased with residual prey abundance (a measure of the deviation from the seasonal trend in prey concentration). The low $\mathrm{T}_{\text {opt }}$ and low $\mathrm{G}_{\max }$ values estimated for 1995 compared with either 1997 or 1999 were consistent with the low prey biomass concentrations reported for 1995 (Buckley \& Durbin 2006). The strong positive correlations between $\mathrm{rG}_{\mathrm{i}}$ and $\mathrm{rT}$ observed for cod and haddock larvae in 1999 were consistent with the high prey biomass concentrations observed that year. A positive relationship between $\mathrm{rG}_{\mathrm{i}}$ and $\mathrm{rT}$ would be expected when food was plentiful and growth was not food-limited. If temperature played the dominant role in determining variability in larval growth rates in the sea, then a strong relationship between $\mathrm{rT}$ and $\mathrm{rG}_{\mathrm{i}}$ should be observed in most if not all years.

The relatively high incidence of starving YSFF observed in 1995 compared with those in either 1997 or 1999 provides further evidence that feeding conditions were poor in 1995.

Our estimates of starvation mortality in YSFF cod and haddock larvae $\left(0.1\right.$ to $\left.9 \% \mathrm{~d}^{-1}\right)$ are comparable to that reported for walleye pollock Theragra chalcogramma (Theilacker et al. 1996). Walleye pollock, Atlantic cod and haddock, all gadoid species, appear to be vulnerable to starvation for a $2 \mathrm{wk}$ period after first feeding. Published estimates of total mortality in cod and haddock larvae on Georges Bank range from 3 to $14 \% \mathrm{~d}^{-1}$ (Lough 1984, Mountain et al. 2003). Our data suggest that for YSFF larvae, much of this mortality may at times be due to starvation as was reported for jack mackerel (Theilacker 1986). The very low incidence of larger, older larvae (size classes 2 and 3) with negative growth rates at the time of capture $(\leq 1 \%$ for both species in our data set) suggests that direct starvation plays a relatively small role in mortality of cod and haddock larvae on Georges Bank, once feeding and growth are initiated. Nevertheless, food-limited growth and the resulting increase in the duration of the vulnerable larval period may be an important factor in mortality of these species during the larval period.

\section{Additional fact ors affecting larval growth and survival}

It is the deviations from the seasonal and ontogenetic trends in food availability and growth rate $\left(\mathrm{rG}_{\mathrm{i}}\right)$ that are most likely related to interannual variability in survival and recruitment (Platt et al. 2003). While prey concentration or, more specifically, the deviation from the seasonal trend in prey concentration may be the most informative variable in this regard, it is difficult, time-consuming and expensive to measure (although new technologies are changing this situation). Consequently, with few exceptions long time series of prey abundance data comparable in duration to available recruitment time series (>30 yr) are generally unavailable. Where these data are available they may be limited in spatial coverage or taxonomic detail (Beaugrand et al. 2003). Often the small naupliar and copepodite stages that make up the bulk of the diet of fish larvae are not adequately sampled. The lack of long time series of prey abundance data increases the need for and the value of proxies for prey abundance for which long time series data are available.

Several environmental variables measured in this study were weakly correlated with $\mathrm{rG}_{\mathrm{i}}$ and may serve as proxies for feeding and growth conditions. Among the environmental variables considered, salinity explained the largest portion of the observed variability in $\mathrm{rG}_{\mathrm{i}}$. Salinity was inversely correlated with both prey biomass concentration (Buckley \& Durbin 2006) and $\mathrm{rG}_{\mathrm{i}}$. High salinity in 1995 likely contributed to these inverse correlations. Prey biomass concentrations and larval growth rates were lowest in 1995 and salinities the highest in the time series. In May 1995 a warmcore ring brought warmer and saltier slope water up onto the southern flank of the Bank (Manning et al. 2001). However, few cod and haddock larvae were collected in this warmer water, and salinities on Georges Bank in 1995 were already higher than the decadal mean before this event, suggestive of a larger scale process (Smith et al. 2001, Mountain 2003). The 1990s was a period of general freshening in the Gulf of 
Maine and Georges Bank, which was attributed to an increased inflow of low salinity surface water from the Scotian Shelf (Mountain 2003). Positive salinity anomalies in 1994 and early 1995 were attributed to reduced freshwater fluxes in late 1993 through early 1995 (Smith et al. 2001). While salinity can directly affect growth and survival of marine fish larvae with maximum rates observed at salinities lower than full strength seawater (Opstad 2003), the relatively small difference in salinity observed between years, about 1 psu, was likely more important as a marker for the productivity of the associated water masses. Although high $\sigma_{\mathrm{t}}$ in 1995 likely contributed to the inverse correlation between density and $\mathrm{rG}_{\mathrm{i}}$, the trend was also apparent in other years. An index of density stratification $\left(\Delta \sigma_{t}\right)$ was weakly correlated with $\mathrm{rG}_{\mathrm{i}}$ of larval haddock but not cod. Peak spawning of haddock is about 1 mo after cod, and haddock larvae appear to be more dependent on development of stratification in the spring (Buckley et al. 1993). Results from earlier studies on Georges Bank have shown that potential zooplankton prey items are concentrated near the thermocline (Incze et al. 1996, Lough \& Mountain 1996) and that growth of haddock was higher in stratified waters compared with that in well-mixed shoal sites (Buckley \& Lough 1987).

As part of the US GLOBEC Program, we have compiled a database on environmental conditions, size, macromolecular composition and recent growth of more than 14000 individual Atlantic cod and haddock larvae collected on Georges Bank between 1995 and 1999. Specific growth rate initially increased rapidly with larval size and increased more slowly through the remainder of the larval period. Growth increased with increasing photoperiod and water temperature between March and May. Over the 5 years of the GLOBEC field program on Georges Bank, a single strong year class of haddock was produced (1998), while recruitment of Atlantic cod was consistently low (Mayo \& Terceiro 2005). Prey abundance was high (Buckley \& Durbin 2006) and growth of both cod and haddock larvae was rapid in 1998. However, feeding conditions and growth rate were similarly favorable in 1997 and 1999, years that produced weak to average year classes of both cod and haddock. These findings are consistent with the notion that favorable feeding conditions and rapid growth during the larval stage are necessary but not sufficient for production of strong year classes of either species.

Acknowledgements. This research is contribution \#325 of the US GLOBEC Program, funded jointly by NOAA and the National Science Foundation. Three anonymous reviewers provided helpful comments on an earlier version of the manuscript.

\section{LITERATURE CITED}

Baumann H, Pepin P, Davidson FJ, Mowbray F, Schnack D, Dower JF (2003) Reconstruction of environmental histories to investigate patterns of larval radiated shanny (Ulvaria subbifurcata) growth and selective survival in a large bay of Newfoundland. ICES J Mar Sci 60:243-258

Bailey KM, Houde ED (1989) Predation on eggs and larvae of marine fishes and the recruitment problem. Adv Mar Biol 25:1-83

Bailey KM, Canino MF, Napp JM, Spring SM, Brown AL (1995) Contrasting years of prey levels, feeding condition and mortality of larval walleye pollock Theragra chalcogramma in the western Gulf of Alaska. Mar Ecol Prog Ser 119:11-23

Baskerville-Bridges B, Kling LJ (2000) Early weaning of Atlantic cod (Gadus morhua) onto a microparticulate diet. Aquaculture 189:109-117

Beaugrand G, Brander $\mathrm{K}$, Lindley JA, Souissi S, Reid PC (2003) Plankton effect on cod recruitment in the North Sea. Nature 426:661-664

Blaxter JHS (1986) Development of sense organs and behaviour of teleost larvae with special reference to feeding and predator avoidance. Trans Am Fish Soc 115:89-114

Bolz GR, Lough RG (1988) Growth through the first six months of Atlantic cod, Gadus morhua, and haddock, Melanogrammus aeglefinus, based on daily otolith increments. Fish Bull US 86:223-235

Brett JR (1979) Environmental factors and growth. In: Hoar WS, Randall DJ, Brett JR (eds) Fish Physiology, Vol. VIII, Bioenergetics and growth. Academic Press, London, p 599-667

Buckley LJ, Durbin E (2006) The relationship between prey abundance and growth rate of Atlantic cod (Gadus morhua) and haddock (Melanogrammus aeglefinus) larvae on Georges Bank. Deep-Sea Res II (in press)

Buckley LJ, Lough RG (1987) Recent growth, biochemical composition and prey field of larval haddock (Melanogrammus aeglefinus) and Atlantic cod (Gadus morhua) on Georges Bank. Can J Fish Aquat Sci 44:14-25

Buckley LJ, Smigielski AS, Halavik TA, Burns BR, Laurence GC (1993) Growth and survival of the larvae of three species of temperate marine fishes at discrete prey densities. II. Cod (Gadus morhua), winter flounder, (Pseudopleuronectes americanus), and silver hake (Merluccius bilinearis). In: Walther BT, Fyhn HJ (eds) Physiological and biochemical aspects of fish development. University of Bergen, Norway, p 183-195

Buckley LJ, Caldarone E, Ong TL (1999) RNA-DNA ratio and other nucleic acid-based indicators for growth and condition of marine fishes. Hydrobiology 401: 265-277

Buckley LJ, Caldarone E, Lough RG (2004) Optimum temperature and food limited growth of larval Atlantic cod (Gadus morhua) and haddock (Melanogrammus aeglefinus) on Georges Bank. Fish Oceanogr 13:134-140

Caldarone EM (2005) Estimating growth in haddock larvae Melanogrammus aeglefinus from RNA:DNA ratios and water temperature. Mar Ecol Prog Ser 293:241-252

Caldarone EM, Buckley LJ (1991) Quantitation of DNA and RNA in crude tissue extracts by flow injection analysis. Anal Biochem 199:137-141

Caldarone EM, Wagner M, St. Onge-Burns JM, Buckley LJ (2001) Protocol and guide for estimating nucleic acids in larval fish using a fluorescence microplate reader. Ref. doc 01-11:1-22, National Marine Fisheries Service, Woods Hole, Massachusetts. Also available at www.nefsc.noaa. gov/nefsc/publications/crd/crd0111/0111.htm 
Caldarone EM, St. Onge-Burns JM, Buckley LJ (2003) Relationship of RNA/DNA ratio and temperature to growth in larvae of Atlantic cod Gadus morhua. Mar Ecol Prog Ser 262:229-240

Campana SE, Hurley PCF (1989) An age- and temperaturemediated growth model for cod (Gadus morhua) and haddock (Melanogrammus aeglefinus) larvae in the Gulf of Maine. Can J Fish Aquat Sci 46:603-613

Campbell RG, Runge JA, Durbin EG (2001) Evidence for food limitation of Calanus finmarchicus production rates on the southern flank of Georges Bank during April 1997. DeepSea Res II 48:531-549

Folkvord A (2005) Comparison of size-at-age of larval Atlantic cod (Gadus morhua) from different populations based on size- and temperature-dependent growth models. Can J Fish Aquat Sci 62:1037-1052

Folkvord A, Ystanes L, Johannessen A, Moksness E (1996) RNA:DNA ratios and growth of herring (Clupea harengus) larvae reared in mesocosms. Mar Biol 126: 591-602

Gallego A, Heath MR, Basford DJ, MacKenzie BR (1999) Variability in growth rates of larval haddock in the northern North Sea. Fish Oceanogr 8:77-92

Green J, Jones R, Brownell S (2004) Age and growth of larval cod and haddock on Georges Bank during 1995 and 1996. Mar Ecol Prog Ser 283:255-268

Heath MR (1992) Field investigations of early larval stages of marine fish. Adv Mar Biol 28:1-175

Heath MR, Gallego A (1997) From the biology of the individual to the dynamics of the population: bridging the gap in fish early life studies. J Fish Biol 51 (Suppl A): 1-29

Houde ED (1978) Critical food concentrations for larvae of three species of subtropical marine fishes. Bull Mar Sci 28: 395-411

Houde ED (1989) Comparative growth, mortality, and energetics of marine fish larvae: temperature and implied latitudinal effects. Fish Bull US 87:471-495

Houde ED (1997) Patterns and trends in larval-stage growth and mortality of teleost fish. J Fish Biol 51 (Suppl A):52-83

Houde ED, Zastrow CE (1993) Ecosystem- and taxon-specific dynamic and energetic properties of larval fish assemblages. Bull Mar Sci 53:290-335

Hunter JR (1981) Feeding ecology and predation of marine fish larvae. In: Lasker R (ed) Marine fish larvae, morphology, ecology and relation to fisheries. Washington Sea Grant Program, University of Washington Press, Seattle, p 34-87

Incze L, Aas P, Ainaine T (1996) Distribution of copepod nauplii and turbulence on the southern flank of Georges Bank: implications for feeding by larval cod (Gadus morhua). Deep-Sea Res II 43:1855-1873

Johannessen A, Bloom G, Folkvord A (2000) Differences in the growth pattern between spring and autumn spawned herring (Clupea harengus L.) larvae. Sarsia 85:461-466

Laurence GS (1977) A bioenergetics model for the analysis of feeding and survival potential of winter flounder, Pseudopleuronectes americanus, larvae during the period from hatching to metamorphosis. Fish Bull US 75:529-546

Laurence GC (1985) A report on the development of stochastic models of food limited growth and survival of cod and haddock larvae. In: Laurence GC, Lough RG (eds) Growth and survival of larval fishes in relation to the trophodynamics of Georges Bank cod and haddock. NOAA Tech Memo NMFS-F/NEC-36, p 83-150

Leggett WC, Deblois E (1994) Recruitment in marine fishes: Is it regulated by starvation and predation in the egg and larval stages? Neth J Sea Res 32:119-134

Letcher BH, James JA, Crowder LB, Rose KA (1996) Variability in survival of larval fish: disentangling components with a generalized individual-based model. Can J Fish Aquat Sci 53:787-801

Lough RG (1984) Larval fish trophodynamic studies on Georges Bank: sampling strategy and initial results. In: Dahl E, Danielssen DS, Moksness E, Solemdal P (eds) The propagation of cod Gadus morhua L. Flodevigen rapportser 1:395-434

Lough RG, Manning JP (2001) Tidal-front entrainment and retention of fish larvae on the southern flank of Georges Bank. Deep-Sea Res II 48:631-644

Lough RG, Mountain DG (1996) Effect of small-scale turbulence on feeding rates of larval cod and haddock in stratified water on Georges Bank. Deep-Sea Res II 43: 1745-1772

Lough RG, Caldarone EM, Rotunno TK, Broughton EA, Burns BR, Buckley LJ (1996) Vertical distribution of cod and haddock eggs and larvae feeding and condition in stratified mixed waters on southern Georges Bank May 1992. DeepSea Res 43:1875-1904

Lough RG, Buckley LJ, Werner FE, Quinlan JA, PehrsonEdwards K (2005) A general biophysical model of larval cod growth applied to Georges Bank. Fish Oceanogr 14: $1-22$

MacKenzie BR, Leggett WC, Peters RH (1990) Estimating larval fish ingestion rates: Can laboratory derived values be extrapolated to the wild? Mar Ecol Prog Ser 67:209-225

Manning JP, Lough RG, Naimie E, Churchill JH (2001) Modeling the effect of a slope-water intrusion on advection of fish larvae in May 1995 on Georges Bank. ICES J Mar Sci 58:985-993

Mayo RK, Terceiro M (eds) (2005) Assessment of 19 Northeast groundfish stocks through 2004. Ground Fish Assessment Review Meeting, Northeast Fisheries Science Center, Woods Hole, Massachusetts, USA, 15-19 August, NEFSC Reference Document 05-13

Meekan MG, Fortier L (1996) Selection for fast growth during the larval life of Atlantic cod Gadus morhua on the Scotian Shelf. Mar Ecol Prog Ser 137:25-37

Mountain D (2003) Variability in the properties of Scotian Shelf water in the Middle Atlantic Bight, 1977-1999. J Geophys Res 108(C1):3014, doi:10.1029/2001JC001044

Mountain D, Berrien P, Sibunka J (2003) Distribution, abundance and mortality of cod and haddock eggs and larvae on Georges Bank in 1995 and 1996. Mar Ecol Prog Ser 263: 247-260

Munk P (1997) Prey size spectra and prey availability of larval and small juvenile cod. J Fish Biol 51 (Suppl A):340-351

Munk P, Heath M, Skaarup B (1991) Regional and seasonal differences in growth of larval North Sea herring (Clupea harengus L.) estimated by otolith microstructure analysis. Cont Shelf Res 11:641-654

Nielsen R, Munk P (2004) Growth pattern and growth dependent mortality of larval and pelagic juvenile North Sea cod Gadus morhua. Mar Ecol Prog Ser. 278:261-270

Opstad I (2003) Growth and survival of haddock (Melanogrammus aeglefinus) larvae at different salinities. The big fish bang. In: Browman HI, Skiftesvik AB (eds) Proceedings of the 26th Annual Larval Fish Conference. Institute of Marine Research, Bergen, Norway, p 63-69

Otterlei E, Nyhammer G, Folkvord A, Stefansson SO (1999) Temperature- and size-dependent growth of larval and early juvenile Atlantic cod (Gadus morhua): a comparative study of Norwegian coastal cod and northeast Arctic cod. Can J Fish Aquat Sci 56:2099-2111

Pedhazur EJ (1997) Multiple regression in behavioral research explanation and prediction. Harcourt Brace College Publishers, Fort Worth, Texas 
Pepin P (1991) Effect of temperature and size on development, mortality, and survival rates of the pelagic early life history stages of marine fish. Can J Fish Aquat Sci 48: 503-518

Pepin P, Evans GT, Shears TH (1999) Patterns of RNA/DNA ratios in larval fish and their relationship to survival in the field. ICES J Mar Sci 56:697-706

Peterson I, Wroblewski JS (1984) Mortality rate of fishes in the pelagic ecosystem. Can J Fish Aquat Sci 41:1117-1120

Pitchford JW, James A, Brindley J (2005) Quantifying the effects of individual and environmental variability in fish recruitment. Fish Oceanogr 14:156-160

Platt T, Fuentes-Yaco C, Frank KT (2003) Spring algal bloom and larval fish survival. Nature 423:389-399

Puvanendran V, Brown JA (2002) Foraging, growth and survival of Atlantic cod larvae reared in different light intensities and photoperiods. Aquaculture 214:131-151

Ricker WE (1979) Growth rates and models. In Hoar WS, Randall DJ, Brett JR (eds) Fish physiology, Vol 8. Bioenergetics and growth. Academic Press, New York, p 677-743

Rilling GC, Houde ED (1999) Regional and temporal variability in growth and mortality of bay anchovy, Anchoa mitchilli, larvae in Chesapeake Bay. Fish Bull US 97:555-569

Smith P, Houghton RW, Fairbanks RG, Mountain DG (2001) Interannual variability of boundary fluxes and water mass properties in the Gulf of Maine and on Georges Bank: 1993-1997. Deep-Sea Res II 48:37-70

Smith PK, Krohn RI, Hermanson GT, Mallia AK, Gartner FH, Provenzano MD, Fujimoto EK, Goeke NM, Olson BJ, Klenk DC (1985) Measurement of protein using bicinchoninic acid. Anal Biochem 150:76-85

Editorial responsibility: Kenneth Sherman (Contributing Editor), Narrangansett, Rhode Island, USA
Sundby S (2000) Recruitment of Atlantic cod stocks in relation to temperature and advection of copepod populations. Sarsia 85:277-298

Suthers IM, Sundby S (1996) Role of the midnight sun: comparative growth of pelagic juvenile cod (Gadus morhua) from the Arcto-Norwegian and a Nova Scotian stock. ICES J Mar Sci 53:827-836

Suthers IM, Frank KT, Campana SE (1989) Spatial comparison of recent growth in postlarval Atlantic cod (Gadus morhua) off southern Nova Scotia: inferior growth in a presumed nursery area. Can J Fish Aquat Sci 46:113-124

Takahashi M, Watanabe Y (2005) Effects of temperature and food availability on growth rate during the late larval stage of Japanese anchovy (Engraulis japonicus) in the Kuroshio-Oyashio transition region. Fish Oceanogr 14: 223-235

Theilacker GH (1986) Starvation-induced mortality of young sea-caught jack mackerel, Trachurus symmetricus, determined with histological and morphological methods. Fish Bull US 84:1-17

Theilacker GH, Bailey KM, Canino MF, Porter SM (1996) Variations in larval walleye pollock feeding and condition: a synthesis. Fish Oceanogr 5:112-123

Wiebe PH, Morton AW, Bradley AM, Backus RH, Craddock JE, Barber V, Cowles TJ, Flierl GR (1985) New developments in the MOCNESS, an apparatus for sampling zooplankton and micronekton. Mar Biol 87:313-323

Xie S, Watanabe Y (2005) Hatch date-dependent differences in early growth and development recorded in the otolith microstructure of Trachurus japonicus. J Fish Biol 66: $1720-1734$

Submitted: September 7, 2004; Accepted: April 10, 2006

Proofs received from author(s): October 5, 2006 